\title{
Lessons from K-12 Education in Asia-Pacific Countries Successful in the PISA: ICT Integration Dimension*
}

\author{
Semra Fiş ERÜMIT ${ }^{* *}$
}

\author{
Esra KELEŞ***
}

\begin{abstract}
This research aims to examine the integration of Information and Communication Technologies (ICT) into the instructional settings in Asia-Pacific countries and states, ranking among the Top 10 in the PISA test. PISA is an OECD's assessment tool which is applied every three years to measure 15-year-olds' ability to use their knowledge in mathematics, science, and reading. PISA was first held in 2000, and it has been observed an increasing number of Asia-Pacific countries and states in the Top 10 over the years. Nowadays, one focus of national education systems is on educational technologies and their impact on teaching processes. Therefore, this study focuses on studies regarding the ICT integration of countries in the Asia-Pacific region and their effects on student performance in the PISA test. The document analysis method was used to examine PISA results and reports, OECD reports, ICT integration projects, and studies on PISA. Successful ICT integration activities of Asia-Pacific countries and states were determined by comparing their efforts for ICT integration across countries. Additionally, studies on ICT integration of the Asia-Pacific countries were compared with the studies conducted in Turkey and inferences were made about the effect of ICT integration studies on the outcomes of PISA.
\end{abstract}

Keywords: Asia-Pacific countries, PISA, ICT integration, Education policies.

\footnotetext{
* Ethics approval was obtained from the Ethics Committee of Trabzon University with a letter dated 27.11.2020 numbered 81614018-000-E.533.

** Orcid ID: https://orcid.org/0000-0002-7161-8903, Dr. Karadeniz Technical University, Turkey, semra727@gmail.com

*** Orcid ID: https://orcid.org/0000-0002-8924-1657, Assoc. Prof. Dr., Trabzon University, Turkey, esrakeles@trabzon.edu.tr
} 


\section{INTRODUCTION}

PISA, the Program for International Student Assessment, is a three-year program conducted by the Organization for Economic Cooperation and Development (OECD) aiming to assess the knowledge and skills of 15 -year-old students (MoNE, 2011). Within the scope of the program, student evaluation tests and questionnaires are developed, their results are evaluated and reported. PISA enables participating countries to assess their own education systems, compare them with others, and identify the strengths and weaknesses of their own systems. PISA results help countries to compare their own education policies, curriculum, teacher competencies, teaching tools and material use with the others. By comparing different education systems, the participating countries have the opportunity to review their national education policies and improve their own education systems (Bakioğlu \& Baltacl, 2019).

PISA, which started in 2000, is open to all countries regardless of whether they are members of OECD or not. The number of participants in the assessment program has increased year by year, and there has been a boom in the participation of Asia-Pacific region countries, especially the states affiliated to China, in the program after 2009. The education systems of these countries have come under the spotlight due to their great success. Since educational technologies are being used extensively in educational environments, it is hard to exclude these technologies from educational environments. Nowadays, various technologies, tools and applications are used in both curriculum and classroom. For this reason, the integration of Information and Communication Technologies (ICT) into the educational process is becoming as important as the national education systems themselves.

\section{The Scope of the PISA}

PISA exam aims to measure international students' skills to cope with real-life challenges as well as their knowledge in reading, mathematics, and science (Prais, 2004). The main goal of PISA is not to measure how well students have learned science, mathematics, and reading in school. It basically analyses students' knowledge and skills and assesses their ability to use this knowledge (Aşkar \& Olkun, 2005; Aydoğdu İskenderoğlu \& Baki, 2011). It also includes surveys for students, parents and school administrators to find out the reasons underlying students' success and failure (OECD, 2012a). The exam component of the PISA consists of questions measuring mathematical, scientific and reading literacy. In addition, the PISA exam has included questions for problem-solving skills since 2003. The purpose of the evaluation of problem-solving skills is to evaluate the cognitive skills in the individual problem-solving process.

To this end, students are asked problems that require exploration and comprehension, formulation, planning and implementation, checking and reflection processes (MoNE, 2011). The PISA exam consists of different question formats such as multiple-choice, open-ended, and closed-ended items. Students are selected through random stratification. First, geographical regions in each country are stratified. Then schools in 
these regions are randomly selected. Finally, 15-year-old students enrolled in these schools are selected at a random basis again.

In the first PISA assessment in 2000, 32 countries participated, 28 of which were members of the OECD. In the session of 2018, 72 countries attended, 37 of which were OECD members (Table 1). The increasing number of participants can be taken as an indicator of the importance that countries attacth to the PISA exam.

Table 1.

Countries Ranking Top 10 at PISA between 2000-2018

\begin{tabular}{|c|c|c|c|c|c|c|c|}
\hline & 2000 & 2003 & 2006 & 2009 & 2012 & 2015 & 2018 \\
\hline 1 & Finland & $\begin{array}{l}\text { Hong-Kong } \\
\text { (China) }\end{array}$ & Finland & $\begin{array}{l}\text { Shanghai } \\
\text { (China) }\end{array}$ & $\begin{array}{l}\text { Shanghai } \\
\text { (China) }\end{array}$ & Singapore & $\begin{array}{l}\text { B-S-J-Z } \\
\text { (China) }\end{array}$ \\
\hline 2 & Canada & Finland & $\begin{array}{l}\text { Hong-Kong } \\
\text { (China) }\end{array}$ & South Korea & Singapore & Japan & Singapore \\
\hline 3 & $\begin{array}{l}\text { New } \\
\text { Zealand }\end{array}$ & South Korea & Canada & Finland & $\begin{array}{l}\text { Hong-Kong } \\
\text { (China) }\end{array}$ & Estonia & $\begin{array}{l}\text { Macau } \\
\text { (China) }\end{array}$ \\
\hline 4 & Australia & Netherlands & $\begin{array}{l}\text { Chinese } \\
\text { Taipei } \\
\text { (Taiwan) }\end{array}$ & $\begin{array}{l}\text { Hong-Kong } \\
\text { (China) }\end{array}$ & $\begin{array}{l}\text { Chinese } \\
\text { Taipei } \\
\text { (Taiwan) }\end{array}$ & $\begin{array}{l}\text { Chinese } \\
\text { Taipei } \\
\text { (Taiwan) }\end{array}$ & $\begin{array}{l}\text { Hong- } \\
\text { Kong } \\
\text { (China) }\end{array}$ \\
\hline 5 & Ireland & Liechtenstein & Estonia & Singapore & South Korea & Finland & Estonia \\
\hline 6 & $\begin{array}{l}\text { South } \\
\text { Korea }\end{array}$ & Japan & Japan & Canada & $\begin{array}{l}\text { Macau } \\
\text { (China) }\end{array}$ & $\begin{array}{l}\text { Macau } \\
\text { (China) }\end{array}$ & Canada \\
\hline 7 & $\begin{array}{l}\text { United } \\
\text { Kingdom }\end{array}$ & Canada & New Zeland & New Zeland & Japan & Canada & Finland \\
\hline 8 & Japan & Belgium & Australia & Japan & Liechtenstein & Vietnam & Ireland \\
\hline 9 & Sweden & $\begin{array}{l}\text { Macao } \\
\text { (China) }\end{array}$ & Netherlands & Australia & Switzerland & $\begin{array}{l}\text { Hong } \\
\text { Kong } \\
\text { (China) }\end{array}$ & $\begin{array}{l}\text { South } \\
\text { Korea }\end{array}$ \\
\hline 10 & Austria & Switzerland & Liechtenstein & Netherlands & Netherlands & $\begin{array}{l}\text { B-S-J-G } \\
\text { (China) }\end{array}$ & Poland \\
\hline 11 & - & Turkey (35) & Turkey (43) & Turkey (41) & Turkey (44) & $\begin{array}{l}\text { Turkey } \\
\text { (52) }\end{array}$ & $\begin{array}{l}\text { Turkey } \\
(40)\end{array}$ \\
\hline N.S. & 265.000 & 275.000 & 400.000 & 475.460 & 510000 & 540000 & 600000 \\
\hline $\begin{array}{l}\text { NPC } \\
/ \text { NOC }\end{array}$ & $\begin{array}{l}32 \\
(28 \\
\text { OECD) }\end{array}$ & $\begin{array}{l}41 \\
(30 \text { OECD) }\end{array}$ & $\begin{array}{l}57 \\
(30 \text { OECD })\end{array}$ & $\begin{array}{l}65 \\
\text { (33 OECD) }\end{array}$ & $\begin{array}{l}65 \\
\text { (34 OECD) }\end{array}$ & $\begin{array}{l}72 \\
(35 \\
\text { OECD) }\end{array}$ & $\begin{array}{l}79 \\
(37 \\
\text { OECD) }\end{array}$ \\
\hline
\end{tabular}

* Color refers to countries in the Asia-Pacific region.

** N.S.: Number of Students

*** NPC/NOC: Number of Participating Countries/Number of OECD Countries

\section{ICT Integration in Education}

In recent years, the economic development of countries in the Asia-Pacific region and their success in PISA exams have drawn attention to the education systems and 
practices of these countries (Bakioğlu \& Baltacl, 2019). Given the current state of technology and its reflections on our lives, undoubtedly, educational technologies and their implications on teaching processes are among the basic building blocks of national education systems. For this reason, educational policies regarding the use of ICT technologies have become an important topic for all countries. It is stated that the national ICT development level positively affects students' academic success in international exams such as PISA and TIMMS (Skryabin, Zhang, Liu, and Zhang, 2015). Table 1 shows that countries in the Asia-Pacific region have become more successful since 2009 while Turkey has performed much worse than expected. For the FATİH project in the first place, considering Turkey's initiatives in educational technologies since 2011, it can be said that ICT activities have proved to be ineffective in increasing the achievement levels or creating the desired flourishing in established tests like PISA. Inspired by the foregoing, the current study was carried out to examine the effects of studies on ICT integration of high-performing countries in the Asia-Pacific region on student achievement in the PISA and compare those studies with equivalents in Turkey. For this purpose, it has been investigated how the countries in the Asia-Pacific region (Japan, South Korea, Hong-Kong-China, Singapore, China, Taiwan-Tapei) that are among the Top 10 in the PISA exams integrate ICT into their educational environments. In addition, studies on ICT integration in Turkey were also investigated, and it was aimed to compare the studies in our country with the studies in the countries in the AsiaPacific region. In this way, it is expected to contribute to the determination of exemplary studies to increase Turkey's success in education. It is also thought that this study will shed light on the reasons for the success of the countries in the Asia-Pacific region in the PISA exams and will help compare the practices in these countries with those in Turkey.

The following sub-problems were determined accordingly:

1. What studies have been conducted for ICT integration into educational settings in $\mathrm{K}$ 12 schools of countries in the Asia-Pacific region?

2. What studies have been conducted for ICT integration into educational settings in $\mathrm{K}$ 12 schools in Turkey?

\section{METHOD}

This section describes the research method, study group and data collection tool used, respectively.

\section{Research Design}

The research was carried out with document analysis, which is among qualitative research methods. Document analysis includes the analysis of written resources containing information about the researched topic (Yıldırım \& Şimşek, 2008). Document analysis requires a review of printed resources, online resources, documents, and data (Bowen, 2009). This method was preferred in order to understand the current educational situation of the Asia-Pacific countries ranking in the PISA Top 10 by 
analysing their studies on ICT integration. In this scope, studies on educational ICT integration carried out by the mentioned countries were searched using specific keywords. Secondly, the documents reached in this way were analysed, and the findings were evaluated in a descriptive analysis. The review covered PISA results and reports published by the OECD between 2000 and 2019, the national curricula of countries enforced by respective Ministry of Education, studies on ICT integration, research reports and academic studies in the field of ICT. Before starting the research, ethics approval was obtained from the Ethics Committee of Trabzon University with a letter dated 27.11.2020 numbered 81614018-000-E.533.

\section{Sample}

The sample of this research consisted of six Asia-Pacific countries and states that were listed in the Top 10 in seven PISA tests given between the years 2000 and 2018 and Turkey. The target countries in the Asia-Pacific region included Japan, South Korea, Hong Kong (China), Singapore, Taiwan-Taipei, Vietnam, Shanghai (China), Macau (China), Beijing, Shanghai, Jiangsu, Guangdong (China) and Beijing, Shanghai Jiangsu, Zhejiang (China). The countries with the highest-scores in PISA from 2000 to 2018 are given in detail in Figure 1.

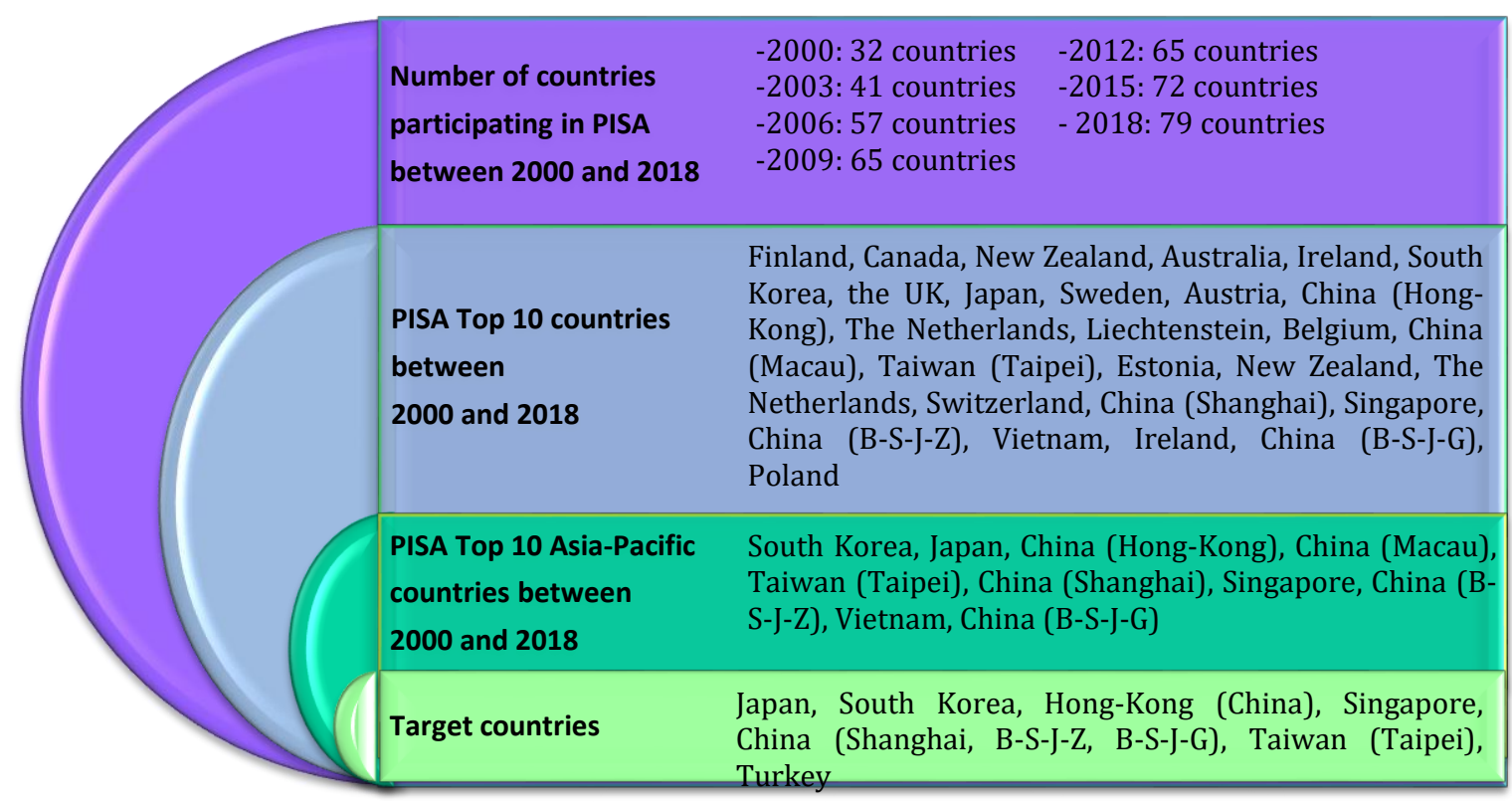

Figure 1. Sample

The target countries are different in terms of population, educational spending per student, number of students per computer at school, percentage of students who can use a computer at school and number of students who use the internet for homework (Table 2). In addition, these countries differ in the form of government. In other words, some of the countries in the study sample are independent countries while some others are 
autonomous regions under the reign of China (Hong Kong, Macau) or the states of China (Shanghai, B-S-J-G and B-S-J-Z).

Table 2.

Facts about Countries/States Participating PISA

\begin{tabular}{|c|c|c|c|c|c|c|}
\hline $\begin{array}{l}\text { Country/ } \\
\text { State }\end{array}$ & $\begin{array}{l}\text { Incidence } \\
\text { of ranking } \\
\text { in PISA Top } \\
10\end{array}$ & Population & $\begin{array}{l}\text { Education } \\
\text { spending per } \\
\text { student }(\$)\end{array}$ & $\begin{array}{l}\text { Number of } \\
\text { students per } \\
\text { computer at } \\
\text { school }\end{array}$ & $\begin{array}{l}\text { Percentage of } \\
\text { students who } \\
\text { can use a } \\
\text { computer at } \\
\text { school (\%) }\end{array}$ & $\begin{array}{l}\text { Percentage of } \\
\text { students using } \\
\text { the Internet } \\
\text { for homework } \\
\text { min once a } \\
\text { week (\%) }\end{array}$ \\
\hline Japan & 6 & $126,573.000$ & 12.120 & 3,6 & 59,2 & 11,3 \\
\hline Singapore & 5 & $5,638.676$ & 5010 & 2 & 69,9 & 30,4 \\
\hline $\begin{array}{l}\text { South } \\
\text { Korea }\end{array}$ & 5 & $25,155.000$ & 11.143 & 5,3 & 41,9 & 11 \\
\hline Vietnam & 4 & $95,540.395$ & 398 & 8,6 & No records & No records \\
\hline $\begin{array}{l}\text { China } \\
\text { (Shangai, } \\
\text { B-S-J-G, }\end{array}$ & 4 & $\begin{array}{l}1 \\
393.000 .000\end{array}$ & 11.069 & 2,9 & 38,3 & 9,7 \\
\hline *Hong & 4 & $7,436.154$ & 5710 & 2,2 & 83,8 & 22,7 \\
\hline $\begin{array}{l}\text { (China) } \\
\text { *Macau }\end{array}$ & 3 & 588.000 & 3874 & 1,3 & 87,6 & 26,7 \\
\hline $\begin{array}{l}\text { (rhina) } \\
\text { Taiwan- } \\
\text { Taipei }\end{array}$ & 1 & $23,78.000$ & 5893 & 5,8 & 78,8 & 28,6 \\
\hline Turkey & - & $82,319.724$ & 4.652 & 44,9 & 48,7 & 28 \\
\hline $\begin{array}{l}\text { OECD } \\
\text { Average }\end{array}$ & & - & 10.520 & 4,7 & 72 & 41,9 \\
\hline
\end{tabular}

(Source: OECD, 2018; Aydın, Selvitopu, \& Kaya, 2018). * Special administrative region of China

It is seen that the states and regions affiliated with China did noticeably well in PISA exams. China was represented in the exam by the state of Shanghai in 2009 and 2012. In 2015, China participated with students selected from 4 states abbreviated as B-S-J-G (Beijing, Shanghai, Jiangsu, Guangdong), and in 2018 with students selected from B-S-J-Z (Beijing, Shanghai, Jiangsu, Zhejiang) states. In different years, China appeared with different names in the PISA lists based on the names of the states that sent the participants. Since these states are affiliated to the Chinese Ministry of Education, the ICT works and activities of China were referred. Forming another group of governmental forms, Hong-Kong and Macau are subject to the same political regime as autonomous regions dependent on China for foreign affairs. These regions are bound with a model 
called "One Country, Two Government Systems" (OECD, 2012). They have autonomous governments and their own education systems. On the other hand, Taiwan is an independent state recognized by only 23 countries in the world today. Since China does not recognize Taiwan's independence, this country takes part in many organizations under the name of the capital Taipei (Tayvan, 2021). As they have a special administrative regime and education system, Hong-Kong and Taiwan were studied as separate countries while the ICT advancements were being analysed.

\section{Data Collection}

Data collection was carried out by reviewing ISI Web of Science, ERIC and Google Scholar. These databases were preferred as they are widely used, and provide a wealth of related publications. Also, it is more convenient to access resources through different databases. The resources reached in this way were subjected to content analysis. Turkish and English keywords were used. The following keywords guided the search: "educational technology", "information and communication technologies", "ICT integration"; "eğitim teknolojileri", "bilgi ve iletişim teknolojileri", and "BíT entagrasyonu". The references of the selected resources were also examined and relevant studies that went unnoticed during the first round were also reviewed. A total of 140 scientific articles were reached, but the number subsequently declined to 58 after omitting those that were relatively irrelevant or provided limited content for the research. Another set of data including OECD and PISA reports, the target countries' curricula and reports on the education systems in their ministries of education was accessed by scanning the institutions' websites. The resources accessed via literature review are as follows:

- PISA results and reports

- Previous studies on PISA

- OECD reports

- Studies on ICT integration

- Books on the education system and ICT integration of the selected countries

- Reports on the education system and ICT of the selected countries

- Academic studies and reports on the education system of the selected countries

- Curricula of the selected countries

\section{Data Analysis}

In this research, document analysis was used to analyse the collected data . The collected documents were reviewed to find an answer to the research questions. More specifically, the studies on ICT policies and educational integration of ICT were analysed based on the following issues:

- The years when studies on ICT integration were intensively applied 
- $\quad$ Revisions to ICT policies

- Projects on ICT integration and their implications for education

- Investments in technical, infrastructure and software for ICT integration

\section{Limitations}

Studies on ICT integration of some of the countries or states examined here could not be reached. For example, adequate data were not found about Macau and Vietnam since their ICT policies or curricula were not available on the websites of their ministries. Additionally, only a very small number of academic studies dealing with ICT integration in those countries were found. Most of them were even in their native language, and they could not be translated. For this reason, Macau and Vietnam had to be omitted from this research despite their high rankings in the PISA.

\section{FINDINGS}

Obtained findings are given on a research question basis. In other words, studies on ICT integration and their results in each of the target countries/states are displayed in response to the first research question in order to rank the countries in PISA top 10 list. For the other research question, findings regarding ICT studies in Turkey are presented.

\section{Studies on ICT Integration at K-12 Level in Asia-Pacific Countries}

\section{Japan}

As one of the countries with advanced technological applications, Japan has achieved satisfactory results in PISA sessions so far. However, it has failed to progress at the same pace in integrating ICT into education policies (Vallance, 2008). In the educational settings of Japan, the use of technology remains at a low level, and ICT has not yet been incorporated into educational processes well enough (UNESCO, 2008). Due to the lack of an effective technology policy particularly targeting teachers and students in Japan, an inadequate number of studies have been conducted on how educators can best implement digital-based learning processes in the school curriculum. However, in the early 2000s, attempts were made to implement ICT-based education policies in Japan. To this end, Information Technologies in Education Project (ITEP) was initiated in 1999 to ensure the use of computers in education in all primary and secondary schools by 2005 (Vallence, 2008). Thanks to this project, all classrooms were equipped with computer and internet access by 2005 . In this framework, videos and visual materials on computer use were prepared to help teachers improve their computer skills and use computers in their lessons. Also, a nation-wide website for educational materials was created. Then in 2001, a strategy centre was established with the intention of making Japan the most developed IT country in the world by 2005 (Naito \& Hausman, 2005). This centre planned a series of activities for ICT use in primary and secondary schools as follows: 
- Providing fast Internet connection to all schools until 2005

- Internet connection in all classes until 2005

- Providing one computer for each student in computer class

- Purchasing necessary information technology applications

The students and teachers' access to ICT resources at school was completed in a short time. Internet connection was built in schools. Most teachers acquired the ability to use a computer (UNESCO, 2008). However, due to the lack of an extensive technology policy addressing teachers and students in Japan, not many practices exist describing how to integrate ICT technologies into the school curriculum. According to the OECD Report for 2012, Japan is a country that shows high success in PISA but uses computers and the Internet for educational purposes at home and at school at a low level (OECD, 2012b). In recent years, the country has been integrating technology into lessons by using electronic boards and tablets used in classrooms (Kanemune, Shirai, \& Tanı, 2017).

\section{South Korea}

The purposes of using ICT in education in South Korea are to strengthen competition in science and technology and catch up with technological and educational changes in the economic, social, scientific and pedagogical domains worldwide. The works towards the integration of ICT into education started in the 1980s and continued with the "Plan for the Renovation of Education" prepared by the Education Renovation Committee in 1995. As a result, computers have been used in all Korean classrooms since 2000. The Ministry of Education, Science and Technology has overseen education and expanded its efforts since 2010 to boost ICT use. To that end, an education plan called "SMART Education" was publicized. The main goal of the SMART program was to complete the digitalization of all school curricula and educational resources by 2015 (Grzybowski, 2013). The objectives of the SMART are as in the following:

- Development of digital textbooks and online evaluation systems

- Creating web environments open to students

- Storage of educational resources on the Internet

- Safe and fast use of educational resources

Since ICT is regarded as one of the keys to South Korea's developmental success, the use of technology and the ability to integrate it into the education system has been a priority among the country's educational aspirations. In the great scheme, South Korea aims to become the educational centre of Southeast Asia and has come a long way with this project (Kim, Cho, \& Lee, 2016). Within the scope of the SMART, students have been provided with tablets, smartphones, and computers. The government planned to provide laptops for all secondary and high-level schools and donate tablets to needy students by 2015 . Tablets and computers provided the use of e-books for students and 
provided access to other resources because smartphones and laptops are considered a pedagogical tool in South Korea. In addition, wireless internet has been provided to all schools, and great importance has been placed on staff training for the integration of ICT into education (Jang, 2014; Lim \& Kye, 2019).

In the SMART Project, cloud storage systems have been created whereby schools can share educational resources with teachers and students faster and easier. In this way, all information and data were transferred to an online server, and all users can access the content at any time. In addition, the Korean Ministry of Education has promoted collaborative learning as it attaches importance to social learning. In this scope, online resources have been intensified, and their use has been made supported, so learner cooperation with teachers and other students through these channels has been enhanced. Currently, online resources are seen as a means of adding to their social skills and personal development, beyond just being a medium for students' exchanging information or asking and answering questions (Lim \& Kye, 2019).

Since 2007, South Korea has been striving for turning all textbooks into digital books. Digital coursebooks have facilitated an easier update of the content and utilizing different multimedia contents. These books have been supplemented with digital games and interactive content, especially for young learners (Jang, 2014). Major investments were made before 2008 for the ICT integration, which started in the early 2000s, and, finally, the system was largely built. Reinforcement efforts continued in the following years (Kim, Cho, \& Lee, 2016).

\section{Hong Kong (China)}

In Hong Kong, ICT integration into schools started with the "Information Technologies in Education Strategy" Project, which has been implemented in three stages since 1998. These projects have served teachers' professional development and created e-learning environments (Education and Manpower Bureau, 1998). Phase one (1998-2003) was mainly directed to lay ICT infrastructure in schools, integrate ICT use into classrooms, and create e-learning environments. The second phase (2004-2007) focused on both technical and pedagogical tasks. In phase three (from 2008 to the present), the focus has been on actualizing student-based e-learning environments (Kong, Chan, Huang, \& Cheah, 2014). Most schools have perceived ICT integration in education by using multimedia presentations and/or animations instead of chalks and blackboards. Nevertheless, schools have successfully managed to lead ICT integration activities and adaptation of curriculum to ICT requirements (Wong \& Li, 2006).

Following the e-learning activities, the Hong Kong government has commenced forming learning communities among teachers to spread the use of ICT in different areas. Teacher materials have been transferred to online environments, and teaching resources have been stored in digital environments. All teachers are now allowed to use the files in these environments, comment on the files, and share information about digital resources (Wong \& $\mathrm{Li}, 2006$ ). 


\section{Singapore}

Singapore is esteemed to be one of the most successful countries in educational technology policies in the Asia-Pacific region. Singapore started ICT studies in the early 90s to integrate the traditional practices of Asian countries with the practices required by contemporary needs (Luke, Freebody, Shun, \& Gopinathan, 2005; Vallance, 2008). Singapore's ICT integration policy basically intends to train students as individuals who improve their own learning processes at school and contribute to the information-based economy and digital citizenship. The First Masterplan for IT in Education (MP1) was developed for this purpose and implemented from 1997 to 2002. It focused on equipping schools with basic ICT infrastructure and having teachers use ICT (Vallence, 2008). To achieve this, all teachers received a 30-hour professional development course given by the Ministry of Education about the integration of ICT into the curriculum. The course aimed to support teachers in teaching word processors, the internet, and other ICT tools and integrate them into the teaching environment (Koh \& Lee, 2008). The participants were trained with an innovative approach to design and implement ICTbased courses and tasks, and activities were conducted to support lifelong learning. Teachers were also involved in activities to support the use of ICT and creative thinking in schools (Kong et al., 2014).

Second Masterplan for IT in Education (MP2) was put into action from 2003 to 2008 with the objectives of ensuring effective and widespread use of ICT in schools, achieving curriculum integration of ICT, and handling teaching and assessment settings to be offered by ICT. The integration of ICT into the curriculum has been an educational milestone in Singapore. A large emphasis was placed on training students for the changing needs of society. At the end of MP1, the teachers reached different levels of competence in integrating ICT into the curriculum. In MP2, the schools were set at liberty to do the integration practices needed by the students during the implementation of the curriculum (Koh \& Lee, 2008).

In 2008, the third Masterplan for IT in Education (MP3) was introduced as a continuation of the preceding ones to enrich students' learning environments and equip students with the necessary competencies by using appropriate ICT tools (Singapore Educational Technology Division, 2008). Finally, in 2015, the fourth Masterplan for IT in Education (MP4) was put into effect with the vision of educating students in the field of informatics. This plan was dedicated to teaching students the necessary skills to become digital citizens competent for the $21^{\text {st }}$ century. Additionally, the web environment was intensively dealt with at that stage so that students could learn anywhere at any time and manage personalized learning (Singapore Educational Technology Division, 2016).

\section{China (Shanghai, B-S-J-G, B-S-J-Z)}

In the early 1990s, the Chinese government amplified works on educational technologies and took initiatives to develop highly qualified computer-aided materials at universities to be used in primary and secondary schools. With the studies carried out 
after 1990, ICT has been put into use to realise inquiry-based teaching. For this purpose, computer-aided materials were designed in different categories to be used in $\mathrm{K}-12$ education. In addition, special software was developed featuring lecturing and subsequent exercises that teachers can use in the classroom and students at home. Those products were quite interesting for students as they hold content for the entrance exams to a higher level of education (Zhang, 2002).

The softwares were also largely used in classroom practices. MS Word has been widely used in lessons such as Chinese and English, MS Excel has been widely used in lessons such as mathematics where calculations are made (Li, 2000). As regards popular software, SketchPad, a geometry application, was translated into Chinese and started to be used in schools. The software referred to above was designed to be used both in CDROM and web-based learning environments.

After 2000, computer laboratories were opened with hardware and network infrastructure in major Chinese cities including Beijing, Shanghai, and Guangzhou. Yet many schools in rural parts of China lack these opportunities (Zhang, 2002). As a remedy, China's Ministry of Education has served a repertoire of free pedagogical videos to 160 million students in all primary, secondary, and high schools, including all rural schools, in compulsory education coverage (Wu, 2014).

The Chinese government has worked to advance teacher development by integrating ICT into classroom practice. Carrying out e-learning activities for teacher development, the government announced the "Five-Year School Education Reform and Development Plan" to be completed in 3 stages between 2000 and 2015. Stage I aimed to equip K12 schools with basic ICT and internet infrastructure and digital educational resources; then, in 2000, the "Broadband Network to Merge Schools" scheme was initiated (Zhu, Gu, Collis, \& Moonen, 2011). Another scheme on the Plan was the "curriculum reform for K12 schools". Thanks to these two initiatives, the teachers were able to integrate ICT into their teaching practice and gain basic skills in this area. The Beijing government considered that some preliminary work was a prerequisite for teachers' integration of ICT into teaching. Hence, the Ministry of National Education has customarily offered technical and theoretical training to teachers to integrate ICT into classroom teaching (Kong, Looi, Chan, \& Huang, 2017).

During the second stage of the Plan (Five-Year School Plan for 2006-2010), the Ministry of National Education of China carried out works to enhance teachers and students' ICT competencies and their rapid integration into the system (Beijing Education Bureau, 2006). This national policy aims at the effective use of government e-learning applications in classroom teaching. For this purpose, the Beijing government has performed activities to increase teachers' participation through e-learning. To ensure the effective integration of ICT into classroom teaching, the teachers were provided with ICT-assisted pedagogical resources, samples, and software. In addition, the National Training Network was set up by which K-12 teachers can exchange and discuss instructional designs in e-learning environments (Kong et al., 2017). 
The last phase was begun in 2015 and characterized by a project on promoting teachers' ICT using competences (Beijing Education Bureau, 2015). The project is devoted to improving teachers' competence in using ICT. On top of that, cooperation has been formed with private companies to develop e-learning resources and deliver online resources to teachers for active use of e-learning environments. In this context, digital campuses have been founded, and e-learning environments have been built to support scientific and effective e-learning and contribute to different aspects such as teaching, research, and school-family ties (Huang, 2009).

\section{Taiwan}

In 1986, Taiwan's Ministry of Education announced a six-year official plan for the use of ICT technologies in schools. The purpose of the plan was to encourage the implementation of computer-assisted education (CAE), teacher training, and the use of CAE in schools (Alessi \& Shih, 1989; Mau, 1988). At the same time, it was targeted to offer computer classes in every secondary school and high school. By 1987, a certain amount of equipment was provided for high schools and secondary schools, thanks to the state funds. The teachers were trained on CAE in the following year, and educational software for CAE was developed with government funding (Alessi \& Shih, 1989).

Although the CAE software was distributed to schools and associated teacher training was completed, it was soon observed that most of the computer hardware was idle, and the software could not be integrated into classroom teaching. Likewise, topics to incorporate computers into the standard curriculum were also not covered in schools. In many schools, computer classrooms were used for administrative purposes rather than instructional ones. (Usa \& $\mathrm{Twu}, 2002$ ). The causes of these shortcomings were the presence of curricula not suitable for CAE, insufficient teacher training, the inadequacy of the authorities in the use of equipment (Hsin, 1994), and the difficulty of adequate monitoring of the implementation by the government due to the immense size of the project. After a while, local schools started to develop and use their own strategies and plans to integrate computers into teaching, leaving the main project scope (Usa \& Twu, 2002).

In the late 1990s, the Ministry reflected on educational technology reform and published a 3-year technology reform plan to consolidate the integration of technology into teaching in 1997 (MOE ROC-Taiwan, 1996). The plan consists of 3 basic components: Information Education Fundamental Plan, National Information Infrastructure (NII) Project, and Medium-Range Plan for Distance Education. The studies carried out within the framework of these 3 projects are as follows:

- To install computer hardware, software, and network infrastructure at all school levels,

- To increase the quality of instruction by means of CAE and computer networks, 
- To improve digital resources on educational technologies and make them available to teachers, students, and ordinary people,

- To use distance learning technology to achieve the goals of lifelong learning,

- To establish good planning, organizing and facilities that will assume long-term and systematic educational technology tasks.

The Ministry of Education of Taiwan then released a second official plan to follow the 3year technology reform plan. The main difference in the latter plan was the formation of network environments. The following achievements were recorded within the framework of this plan (MOE ROC-Taiwan, 1998):

- Preparing ICT curriculum to be initiated at primary school level,

- Giving professional computer skills training to meet ICT needs,

- Integrating ICT in all fields using teaching strategies,

- Building network structures that will help distance learning,

- Creating online platforms for information sharing.

Compared to the previous official plans, it can be understood that these five objectives targeted more specific tasks. However, they reported a drawback: an instructional design coinciding with these objectives was not in effect. It was stated that the Ministry showed great interest in technological developments, but it overlooked individual differences and students' learning strategies (Usa \& Twu, 2002).

Distance education studies have been relatively more important than other educational technology initiatives in Taiwan. The government has heavily invested in researching and developing e-learning since the 1980s. In 1997, a 10-year program was created on the establishment of ICT infrastructure in schools, which marked the starting of elearning studies in Taiwan. In this regard, great importance has been placed on developing content and creating hardware infrastructure for K-12 schools. Then, the third phase (2009-2014) was built on the preceding phases, with a focus on the following issues (Kong et al., 2014):

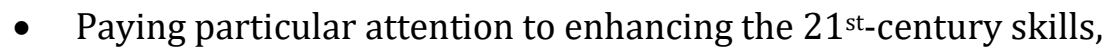

- Embedding digital literacy in the curriculum,

- Launching the mobile learning program

From 1997 to 2002, the Taiwanese government preferred to shift efforts to hardware infrastructure for teachers to use ICT tools in the classroom. With the "Reading of Tomorrow" Program started in 2013, the Ministry of National Education appointed consultant scholars in schools to organize a variety of activities and sessions such as professional development studies, workshops, conferences, and online courses for teachers and school managers. The aim of all those works was to modernize schools' ICT 
infrastructure and train teachers in a way to improve e-learning environments and the

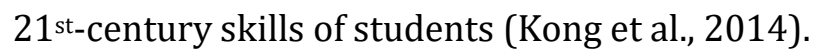

\section{Studies on ICT Integration at K-12 Level in Turkey}

Efforts regarding the use of ICT in education in Turkey were accelerated after 1984, when computers began to be used in the educational context (Uşun, 2004). In 1985, within the scope of transition to computer-assisted education (CAE), computer laboratories were started to be established in schools (MoNE, 2003), and in-service training was provided for teachers to start practising CAE during the same period. Then, the Sixth Five-Year Development Plan in 1989 and the Seventh Five-Year Development Plan in 1996 brought to the agenda regarding the manifestation of technological developments in the education curriculum (Starateji ve Bütçe Başkanlığl, 2019).

In Turkey, ICT developments have always been closely associated with CAE. At the end of the 80s, the Scientific and Technical Research Council of Turkey (TÜBITAK) began its attempts to provide schools with ICT infrastructure and software, and they were supported by the private sector and universities (Keser, 2011). In relation to those projects, it was stated that students' interest in using ICT technologies increased; however, teachers were not knowledgeable enough about the use of these technologies, and the software sent to schools was not compatible with the curriculum (Küpçüoğlu, 2008). The Ministry of National Education (MoNE) implemented several projects funded by the World Bank, such as the Industrial Schools Project (1985-1994), the Non-Formal Vocational Education Project (1987-1995) and the National Education Development Project (1990-1999). Thanks to the projects, the Ministry continued establishing computer laboratories and infrastructure at a faster pace. On these projects, teachers were trained on computer literacy (Fiş Erümit, Gedik, \& Göktaş, 2016). Although the World Bank reported that the projects were completed successfully, the outcomes were not found successful enough in reality. For example, hardware infrastructure was installed, but the use of hardware could not reach the desired level. Most of the teachers did not have the necessary knowledge and skills to use the hardware because teachers and school administrators could not access adequate in-service training on ICT integration, and the curriculum could not be aligned with ICT integration (Akbaba Altun, 2006).

In 1995, instructional software was developed by the MoNE in cooperation with TÜBITTAK and the products were sent to schools whose infrastructure was ready (Akkoyunlu \& İmer, 2012). Then in 1998, the first phase of the Basic Education Project was opened with the objectives of using ICT tools in all levels of 8-year compulsory education and teaching students certain skills such as access to information and problem-solving skills as active learners (Starateji ve Bütçe Başkanlığl, 2019). During these years, hardware and software investments were increased, and ICT integration works were speeded up. In the second phase of the Basic Education Project, the establishment of ICT classes and the purchase of software was sustained. Additionally, in-service training on ICT integration was organized for formator teachers who were 
supposed to work in primary education and handle hardware and software issues on the ground (MoNE, 2005).

In 1998, the Ministry of National Education and the World Bank Economic Development Institution implemented the World Link Project in 15 countries in order to ensure the common use of ICT in education (Gürcan, 2008). The aim of this project, which was implemented in 22 high schools in 15 provinces across Turkey, was to create a platform where teachers and students from various countries can reach over the Internet. Within the scope of the project, the students were provided with a medium to share their information via the Internet and to propose projects jointly with other schools (Erçil Çağlltay, 2000).

Then in 1999, the MoNE started implementing the Curriculum Laboratory Schools Model (MLO), which aimed to elevate the quality of education. Within the scope of the project, educational materials were provided for primary and secondary schools in 23 provinces around the country. In addition, schools were provided hardware items such as computers, printers, fax machines, overhead projectors, scanners, and TVs. MLO schools set an example for other schools as a prototype in their region (Kılış, 1998). As a result of the project, the number of computers and computer laboratories in schools increased, and the Internet connection increased in schools (\%17) thanks to the services of the MoNE (MoNE, 2002).

In 2003, MoNE set off to equip all public schools with Internet connections in order to encourage e-learning. All schools finally had Internet access by 2006 (Eryllmaz \& Salman, 2014). In 2005, free textbooks were given out to students in compulsory education, and all students began learning the same content (Bayrakçı, 2005). In 2006, the MoNE provided students free software needed in interactive language instruction (DynEd) to serve foreign language teaching (Yiğit, 2013).

Another initiative to expand ICT Technologies, FATİH (Movement of Enhancing Opportunities and Improving Technology), came in 2011. The project aimed to offer equal opportunities in education and reach more effective use of ICT tools in primary, secondary, and high schools (MoNE, 2012). In that context, it was planned to complete hardware and software infrastructure, prepare educational e-contents, run in-service training for teachers, ensure the use of ICT and the effective use of ICT integrated education programs (MoNE, 2020a). On the final beneficiary side of the project, it was planned to give each student a tablet, reconstruct the school's Internet infrastructure, and place interactive boards in classrooms. Finally, ICT technologies were installed in every classroom (MoNE, 2012b). In this scope, Education Information Network (EBA) was published on the Internet in 2012 for the use of e-content. EBA is a platform embedding e-content for every grade level created by using ICT tools. In this way, interactive and educational content became open to teachers for reference during lectures and to students for individual studies (Fiş Erümit, Gedik, \& Göktaş, 2016). EBA is constantly kept up to date with its renewed contents and applications (MoNE, 2012). 


\section{DISCUSSIONS AND CONCLUSION}

This research reviews the studies on how PISA Top 10 Asia-Pacific countries integrate ICT into their education processes and what ICT policies they pursue. This section is devoted to giving an account of studies on the ICT integration carried out in the target countries and Turkey comparatively. Since the PISA test is held comprehensively and regularly in many countries, its results say a lot for comparing education policies of the countries or states and imposing amendments mandated by the age (OECD, 2009). For this reason, the present research is thought to be significant in terms of comparing the ICT integration policies of the participating countries or states. With the globalization of the economy and the leaps in technology, there has been a rapid change and development in information and communication technologies, and educational environments have had to keep up with this pace of change. The rapid change in ICT has also affected education reforms and reshaped education. It is argued that the momentum recently gained by most world states is an outcome of ICT reforms and planning (Wong $\& \mathrm{Li}, 2006)$. Given that the education process is a whole, it can be said that the success in PISA is an outcome of successful reforms in the education system, and this has been directly related to the integration of ICT.

While the USA and European Union member countries have experienced economic recession after the 2000s, the economy of countries in the Asia-Pacific region, especially in China, has started to rise (Özekicioğlu and Kılıç, 2017). In a similar vein, these countries have taken top ranks in international measurements like PISA. This global change undoubtedly has to do with the development plans and education reforms of the countries. Evidence exists that ICT integration in education has received great importance in the countries under examination, especially after 2000, and schools have been equipped with reasonable infrastructure, hardware, equipment, and educational materials at the expense of huge budget spending. It is thus clear that the ICT integration works of the Asia-Pacific region countries will much help make sense of this incredible change.

On the other hand, although many studies on ICT integration have been carried out in Turkey, it is seen that different lessons can be drawn from studies on ICT integration of countries in the Asia-Pacific region, whose ranking is higher than Turkey's in PISA. When the studies on the integration of technology into educational environments are examined, it is understood that ICT cannot be used effectively only with technological studies. Instead, the process should be considered more comprehensively (Çelen, Çelik, \& Seferoğlu, 2011; Yurttaş Kumlu, 2018). It is seen that China and Singapore launched comprehensive ICT integration works in the 90s, and the same happened in Japan, South Korea, Hong Kong, and Taiwan in the early 2000s. In Turkey, it is seen that studies on integration increased in the 90s. In those years, $85 \%$ of schools in England, France, Italy and Belgium had already been connected to the Internet.

This is proof that Turkey was behind the European countries in ICT integration at the time (Ylldı, 2008; Topu, 2010). When compared with the Asia-Pacific countries and 
states, it is seen that Turkey accelerated its studies on ICT integration in the same years as China and Singapore, earlier than Japan, South Korea, Hong Kong, and Taiwan. In terms of population density, Turkey has a larger population than Taiwan, South Korea and Hong Kong, but its population is smaller than that of Japan and China. It is of interest that Japan and Chine outdistance Turkey at PISA in spite of their much larger population and density of students. Although education spending per student is accepted as a factor in increasing the quality of education, such spending is reported to explain only $9 \%$ of student achievement (Kılıçaslan \& Yavuz, 2019). It was also stated that China chooses students from certain provinces for the PISA exam since its average national success level comes at the risk of decreasing if students from rural areas are selected (OECD, 2018). Turkey's ICT integration works look like those of the countries in the Asia-Pacific region. Turkey has particularly gained momentum in the ICT integration area with the project of FATIH. Still, the performance of ICT-related works or activities in schools does not directly lead to a climb in student achievement. A major school change process is required for effective ICT use (Honey, Culp, \& Carrigg, 2000). It was stated that ICT is a concept to be taken as a part of reforms in the school system and culture (Bober, 2002). For example, it is contended that the Confucius philosophy plays a big role in South Korea and China and pushes student achievement upwards by showing its effect on school culture. In these societies, education is respected, and educated people are regarded as the most established individuals in the community. Also, families do not avoid putting their children in strict education for long hours (Bakioğlu \& Baltacl, 2019).

It was pointed out that the dissemination of digital resources in the scope of the SMART project in South Korea proved beneficial in developing students' creativity, information literacy and problem-solving skills. In addition, the teachers stated that the success of the students in many courses was positively affected by this project and their communication and learning skills improved (Lim \& Kye, 2019). On the other hand, the teachers expressed their belief that a profound change can be seen in ICT competences only if a continuous fund is provided to education, ICT-related personal development is supported, financial resources are allocated to education appropriately, and software support is extended (Wong \& Li, 2006). On the whole, the SMART project could strengthen the current education system of South Korea, which was ranked 29th in the global education rankings. SMART also supported ICT studies in South Korea and eliminated inequality in education by making ICT available to all students. With the SMART project, ICT contributed to the students' academic achievement (Jang, 2014). Thus, it is needed to use ICT opportunities in a way to prepare students for the future. Among all OECD countries, Turkey is among the countries where students are affected by socioeconomic imbalances the most (Bozkurt, 2014). At this point, the importance of studies on ICT integration to maintain both high quality and equality becomes evident. Although FATİH looks noteworthy in terms of its emphasis on the provision of hardware, infrastructure, and digital content, the overall result could have been better if the project activities had been carried out by the Ministry, teachers, students, and parents in cooperation. Thus, it may be possible for the Ministry to provide the 
necessary opportunities for socio-economically disadvantaged students and provide an opportunity for equality in education.

The rankings in international tests such as PISA, TIMMS, and PIRLS cannot be accounted for just respective educational investments and ICT integration policies of countries, but also the quality of all stakeholders participating in the education process must be considered. In a comparative study by Özkan, Özkan and Güvendir (2019) on the professional development of teachers in schools of Turkey and Singapore, the proportion of teachers who attended professional training was found to be much higher in Singapore than in Turkey. Referring to the big role played by teachers in the alteration process in school, it was stated that teacher quality is one of the most important factors explaining success in education (Tygret, 2017; Vogt \& Rogalla, 2009). In addition, the OECD report indicated that Singapore, which has been in the Top 10 in PISA since 2009 and ranked $1^{\text {st }}$ in 2015 , has reached that level of success mainly due to the quality of teachers (OECD, 2018). Singapore's education system is even known to be one of the world's best education systems. The country provides constant support and opportunities for teachers' professional development. Yardımcıŏglu and Gürdal (2012) emphasized the quality of the educational process and institutionalization matter in achieving the desired success from education. It was asserted that high-achievers such as Singapore, South Korea, and Japan owe their PISA success to the planning in all areas of the education process and the meticulous implementation of these plans. They even consider and schedule elective courses as factors that will increase students' success levels, so they plan those lessons with due diligence (Çiftçi \& Özok, 2013). It can be suggested that adapting ICT to the classroom environment and education should not be the reference point for success. Rather, ICT integration attempts are likely to produce the desired level of success only through holistic approaches to the education environment by supporting teacher training, school culture and basic sciences with ICT studies, and efficient implementation of elective and compulsory courses. As a matter of fact, despite the fact that Japan, one of the main technology producing countries, started studies on ICT integration later than other countries, its success in PISA is the best example of a holistic approach to the educational environment. In relation to the PISA, it is thought-provoking that China has a massive territory and has recently succeeded in PISA by giving the test to students only in selected provinces. Thus, attendance of students from all provinces of China at a random basis could decrease the country's PISA ranking (Tanrısevdi \& Kıral, 2018). However, Shanghai and Hong Kong, on behalf of China, Japan and Singapore as individual countries, regard the education process as not just a necessity. Instead, they take it as the beginning of all kinds of societal change. Bearing this in mind, it can be inferred that the achievement of all kinds of educational policies depends on the perspective of communities about these innovations. Therefore, any changes made, including ICT integration works, need to be compatible with local cultures, or the overall education culture needs to be changed completely. 
Serious investments have been made regarding ICT integration in Turkey, especially since the 90s, but there have been problems with integrating these technologies into the educational environment and using them effectively. In particular, problems arising from efficient and effective use of the tools and technologies provided to schools still prevail (Akbaba Altun, 2006; Çakır \& Yıldırım, 2009; Akıncı, Kurtoğlu, \& Seferoğlu, 2012; Şendurur \& Arslan, 2017). The main causes of these problems are the lack of sufficient educational software, inadequate in-service training on ICT integration for teachers and administrators, teacher expectations towards ready-to-use contents, technology-method confusion of teachers, incompatibility of the curriculum with ICT integration and MoNE's transition to new projects without adequate evaluation of previous projects (Fiş Erümit et al., 2016; Özdemir, 2010; Şendurur \& Arslan, 2017). In addition, emphasis was placed on the need for teachers' complete fulfilment of their duties for ICT integration, and it was found out that teachers in Turkey could not meet up expectations in this regard (Göktaş, Yıldırım, \& Yıldırım, 2008; Usluel, Kuşkaya Mumcu, \& Demiraslan, 2007; Doğan, Çınar, \& Seferoğlu, 2016; Özkan, Özer Özkan, \& Acar Güvendir, 2019). Still, it is possible to see the outcomes of the investments in educational technology in the context of Turkey despite deficiencies in practice. As an example, Turkey was able to switch to distance learning within a period as short as one week following the halt of formal education because of the global Covid-19 pandemic outbreak in mid-2020. MoNE could manage to carry out distance education across the whole country by means of the content portal called EBA, which had been founded and enriched by the Ministry in the previous years, and 3 EBA TV channels, which started broadcasting instantly as soon as the outbreak of the pandemic. Implementing synchronous as well as asynchronous lessons online and instruction via EBA TV, Turkey has become one of the two countries in the world conducting distance education nationwide. China, which is at the top of PISA, has also been one of the countries that allow students to receive education on the internet during this pandemic process. (MoNE, 2020b). For the case of China, it can be suggested that its reformations of educational technologies and investments in elearning have facilitated the country's transition to this mode of teaching. Likewise, in the sample of Turkey, the Ministry of National Education could have succeeded in rapidly integrating the infrastructure, content and applications into the distance education process, apparently due to the investments which had been made in educational technologies for years. As a result of the research, the studies that countries prioritize in ICT integration studies are given in Figure 2. 


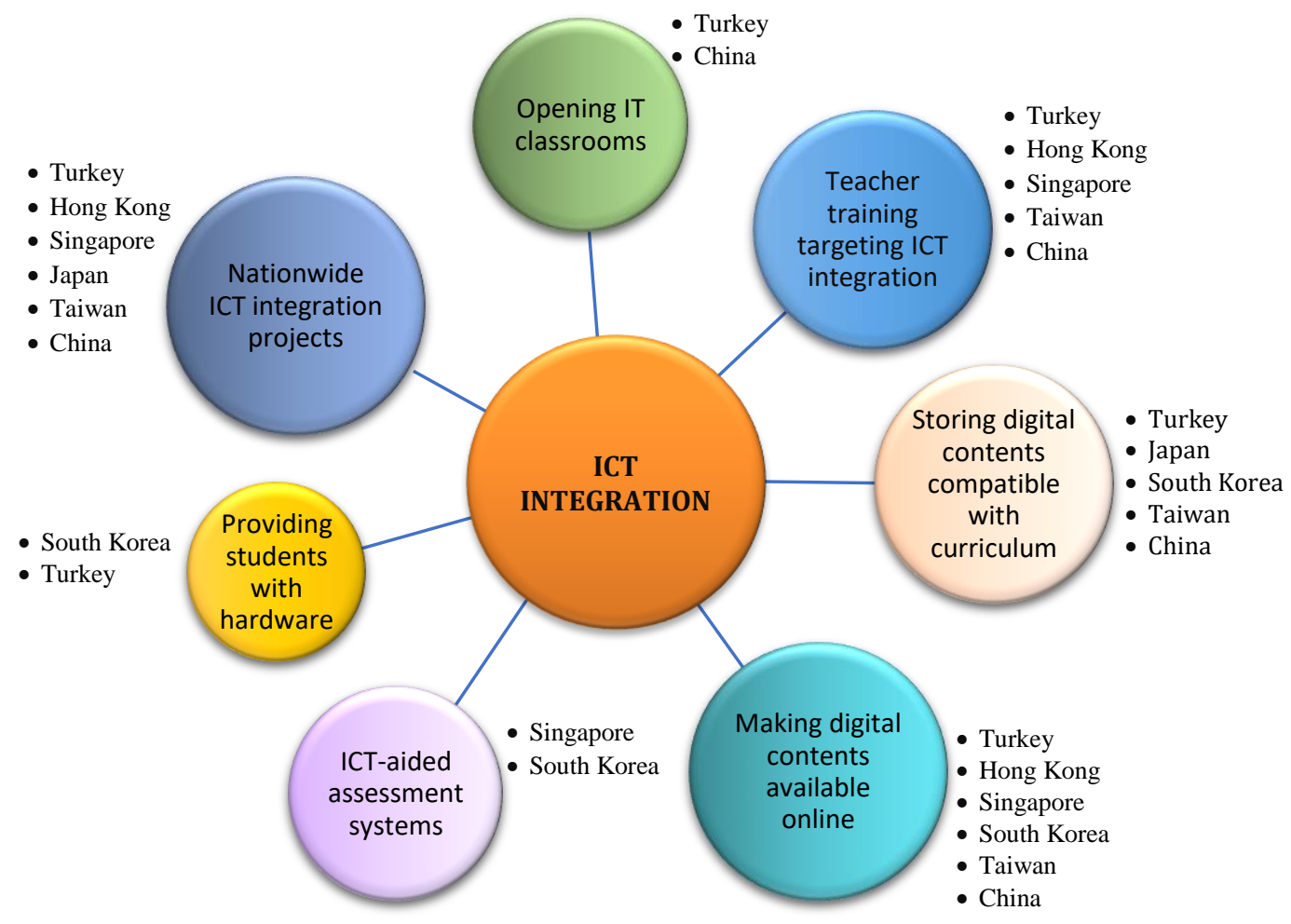

Figure 2. Studies on Educational ICT Integration in Target Countries/States

As shown in Figure 2, the countries and states in this research mostly launched large projects at a national scale and allowed access to digital content as a part of ICT integration. The nationwide projects mostly cover the provision of hardware infrastructure and the Internet connection. Other prioritized works or activities included providing digital content conforming to the curriculum, teacher training for ICT integration, ICT-based assessment systems, opening IT classes, and providing students with hardware such as tablets and phones, respectively.

\section{RECOMMENDATIONS}

Considering the results obtained from this research, the following recommendations can be proposed for realising ICT integration practices in Turkey:

- In Turkey, a number of ICT integration projects have been implemented so far. But challenges have been faced in putting the phenomena into practice and in harmonizing teachers, students, and school culture with these projects. To overcome such challenges, special project monitoring and coordination units should be formed in MoNE responsible for evaluating the integration efforts 
from schools, teachers, and students' points of view. These units need to make their evaluations without ceasing the programs or projects and make revisions quickly.

- In the actualisation of integration works, teachers have a pivotal role. For this reason, it seems to be a sheer need to give teachers extensive and satisfactory training on professional development and technology integration, and MoNE should support teachers' activities in this sense. Also, teachers should be obliged to carry out individual works in their own branch and technology integration every year. They should be encouraged to participate in a comprehensive project (R\&D projects, TÜBITAK-funded projects, European Union-funded projects, etc.) once in 5 years. In this context, studies should be followed up with an evaluation system to encourage those who are not successful in improving their studies and in rewarding those who are successful.

- In the digital age, abundant and satisfying teaching materials are needed by teachers and students. Bearing this in mind, it looks necessary to enrich the content on the EBA and add new and high-quality content to the courses with little or no content.

Besides, some recommendations are brought particularly for technology integration studies of countries and PISA assessments:

- Comparative studies can be planned to discuss reasons for students' success and failure and students' access to technology outside of school in individual countries by looking at the results of the questionnaires applied to students, parents and school administrators within the scope of PISA.

- The distribution of formal education via distance education throughout the world during the Covid-19 pandemic has once again reminded the importance of the technological infrastructure and competencies of countries. Future research can look into the works done in this process and the implications of this process for the PISA exams.

\section{References}

Akbaba Altun, S. (2006). Complexity of Integrating Computer Technologies into Education in Turkey. Educational Technology \& Society, 9(1), 176-187. Retrieved from: https://www.jstor.org/

Akıncı, A., Kurtoğlu, M., \& Seferoğlu, S. S. (2012). Bir teknoloji politikası olarak FATïH projesinin başarılı olması için yapılması gerekenler: Bir durum analizi çalışması [What needs to be done for the FATIH project to be successful as a technology policy: A 
situation analysis study]. Akademik Bilişim Konferansında sunulan bildiri, Uşak Üniversitesi, UŞAK. Retrieved from: https://ab.org.tr/ab12/bildiri/160.pdf

Aşkar, P., \& Olkun, S., (2005). PISA 2003 Sonuçları Açısından Okullarda Bilgi ve İletişim Teknolojileri Kullanımı [Use of Information and Communication Technologies in Schools in Terms of PISA 2003 Results]. Eğitim Araştırmaları Dergisi, 19, 15-34. Retrieved from: https://www.ebsco.com/

Aydın, A., Selvitopu, A., \& Kaya, M. (2018). Eğitime Yapılan Yatırımlar ve PISA 2015 Sonuçları Karşılaştırmalı Bir İnceleme [A Comparative Analysis of Investments in Education and PISA 2015 Results]. Ilköğretim Online, 17(3), 1283-1301. Retrieved from: https://www.ilkogretim-online.org/

Aydoğdu İskenderoğlu, T., \& Baki, A. (2011). İlköğretim 8. Sınıf Matematik Ders Kitabındaki Soruların PISA Matematik Yeterlik Düzeylerine Göre Sınıflandırılması [Classification of the Questions in the Primary 8th Grade Mathematics Textbook According to PISA Mathematics Proficiency Levels]. Eğitim ve Bilim, 36(161), 287301. Retrieved from: http://egitimvebilim.ted.org.tr/index.php/EB

Alessi, S. M., \& Shih, Y.F. (1989). The growth of computer-assisted instruction in Taiwan schools. Computers and Education, 13(4), 337-341. doi: 10.1016/03601315(89)90049-3

Bakioğlu, A., \& Baltacı, R. (2019). Çin'de Eğitim [Education in China]. Ankara: Nobel Akademi Yayıncılık.

Bayrakçı, M. (2005). Ders kitapları konusu ve ilköğretimde ücretsiz ders kitabı dağıtımı projesi [The subject of textbooks and the project of distribution of free textbooks in primary education]. Milli Ĕgitim Dergisi, 165, 7-20. Retrieved from: https://dhgm.meb.gov.tr/

Beijing Education Bureau. (2006). The 11th municipal plan of school education from 2006 to 2010. Retrieved from: http://www.gov.cn/test/2006-02/07/content_180521.htm.

Beijing Education Bureau. (2015). Beijing initiated the project of enhancing K-12 inservice teachers' competency in infusing ICT into education. Retrieved from: http://www.moe.edu.cn/publicfiles/business/htmlfiles/moe/s5147/201505/18773 4.html.

Bober, M. J. (2002). Technology integration: The difficulties inherent in measuring pedagogical change. TechTrends, 46(1), 21-23. Retrieved from: https://www.springer.com/journal/11528

Bozkurt, B. Ü. (2014). PISA 2000'den PISA 2009'a Güney Kore'de okuma becerisinin gelişimi [Development of reading skill in South Korea from PISA 2000 to PISA 2009]. Eğitim ve Bilim, 39(173), 140-154. Retrieved from: http://213.14.10.181/index.php/EB/article/view/1949

Bowen, G. A. (2009). Document analysis as a qualitative research method. Qualitative Research Journal, 9(2), 27-40. doi:10.3316/QRJ0902027. 
Çakır, R., \& Yıldırım, S. (2009). What Do Computer Teachers Think About the Factors Affecting Technology Integration in Schools? Elementary Education Online, 8(3), 952964. Retrieved from: https://dergipark.org.tr/tr/pub/ilkonline

Çiftçi, S., \& Özok, H. İ. (2013). Türkiye'de ve Dünya'da seçmeli dersler: PISA ve TIMSS sınavlarının etkililiği [Elective courses in Turkey and in the world: The effectiveness of PISA and TIMSS exams]. Tanhan, F., Aslan, C. and Taşkın, N. (Eds.), Kesintili on iki yıllık zorunlu eğitim modelinde seçmeli dersler sempozyumu (s. 112-123) içinde. Van, Türkiye: Yüzüncü Yll Üniversitesi. Retrieved from: https://www.yyu.edu.tr/images/files/sempozyum.pdf\#page=122

Çelen, F. K., Çelik, A., \& Seferoğlu, S. S. (2011). Türk eğitim sistemi ve PISA sonuçları [Turkish education system and PISA results]. Akademik Bilişim Konferansında sunulan bildiri, İnönü University, Malatya. Retrieved from: https://ab.org.tr/ab11/

Doğan, D., Çınar, M., \& Seferoğlu, S. S. (2016). “One Laptop per Child” projects and FATIH project: A comparative examination. SDU International Journal of Educational Studies, 3(1), 1-26. Retrieved from: https://dergipark.org.tr/tr/pub/sduijes

Education Manpower Bureau (1998). Information Technology for Learning in a New Era: five-year strategy 1998/99 to 2002/03. Hong Kong: Education Manpower Bureau, Hong Kong SAR. Retrieved https://www.info.gov.hk/archive/consult/1998/ited-e.pdf

Eryılmaz, S., \& Salman, Ş. (2014). Fatih projesi kapsamında yer alan öğretmen ve öğrencilerin projeden beklentileri ve bilişim teknolojileri kullanımına karşı algıları [The expectations of the teachers and students involved in the Fatih project from the project and their perceptions towards the use of information technologies]. Elektronik Mesleki Gelişim ve Araştırmalar Dergisi, 2(1), 46-63. Retrieved from: https://dergipark.org.tr/tr/pub/yorumyonetim

Fiş Erümit, S., Gedik, N., \& Göktaş, Y. (2016). Türkiye'de Öğretim Teknolojilerinin Gelişimi: 1984-2015 Dönemi [Development of Instructional Technologies in Turkey: 1984-2015 Period]. K. Çağıltay and Y. Göktaş (Eds), Öğretim Teknolojilerinin Temelleri Teoriler, Araştırmalar, Eğilimler (s. 58-79) içinde. Ankara: Pegem Akademi.

Grzybowski, M. (2013). Educational technologies in South Korea. General and Professional Education, 2013(1), 3-9. Retrieved from: http://genproedu.com/paper/2013-01/003-009.pdf

Gürcan, H. (2008). Bahçeşehir Fen ve Teknoloji Lisesi Öğrencilerinin BT Yeterliliklerinin Ölçülmesi İçin Bir Model [A Model for Measuring IT Competencies of Bahçeşehir Science and Technology High School Students.]. (Unpublished Masters' Thesis). Bahçeşehir University, İstanbul.

Göktaş, Y., Yıldırım, Z., \& Yıldırım, S. (2008). The Keys for ICT Integration in K-12 Education: Teachers' Perceptions and Usage. H. U. Journal of Education, 34(1), $127-$ 139. Retrieved from: http://www.efdergi.hacettepe.edu.tr/ 
Hsin, S.C. (1994). The Dynamism and Flexibility of Computer Technology Implementation in the Middle Schools in a Centralized Educational System. Paper presented at the Annual Meeting of the American Educational Research Association, New Orleans, LA. Retrieved from: https://files.eric.ed.gov/fulltext/ED373776.pdf

Huang, R. H. (2009). What digital campus should focus on? Beijing Education, 8, 6-7.

Jang, S. (2014). Study on service models of digital textbooks in cloud computing environment for SMART education. International Journal of u-and e-Service, Science and Technology, 7(1), 73-82. Retrieved from: http://sersc.org/journals/index.php/ijunesst

Kanemune, S., Shirai, S., \& Tani, S. (2017). Informatics and programming education at primary and secondary schools in Japan. Olympiads in Informatics, 11(2017), 143150. Retrieved from: https://ioinformatics.org/page/ioi-journal/1

Keser, H. (2011). Türkiye'de Bilgisayar Eğitiminde İlk Adim: Orta Öğretimde Bilgisayar Eğitimi İhtisas Komisyonu Raporu [The First Step in Computer Education in Turkey: Computer Education Specialization Commission Report in Secondary Education]. Eğitim Teknolojisi Kuram ve Uygulama, 1(2), 83-94. Retrieved from: https://dergipark.org.tr/tr/pub/etku

Kılıçaslan, H., \& Yavuz, H. (2019). PISA Sonuçları ile Türkiye'de Eğitim Harcamaları İlişkisi [The Relationship between PISA Results and Education Expenditures in Turkey]. Bilgi Sosyal Bilimler Dergisi, 21(2), 296-319. Retrieved from: https://dergipark.org.tr/tr/pub/bilgisosyal

Kim, T., Cho, J. Y., \& Lee, B. G. (2012). Evolution to smart learning in public education: a case study of Korean public education. T. Ley ve diğerleri (Ed), Proceedings of IFIP International Federation for Information Processing (s. 170-178) içinde. Berlin, Heidelberg: Springer.

Koh, T. S., \& Lee, S. C. (2008). Digital Skills and Education: Singapore's ICT Masterplanning for the School Sector. In S. K. Lee, C. B. Goh, B. Fredriksen, \& J. P. Tan (Eds.), Toward a better future: Education and training for economic development in Singapore since 1965 (pp. 167-190). Washington, DC: The World Bank.

Kong, S. C., Chan, T.-W., Huang, R., \& Cheah, H. M. (2014). A review of e-Learning policy in school education in Singapore, Hong Kong, Taiwan, and Beijing: Implications to future policy planning. Journal of Computers in Education, 1(2), 187-212. Retrieved from: h https://www.springer.com/journal/40692

Kong, S. C., Looi, C. K., Chan, T. W., \& Huang, R. (2017). Teacher development in Singapore, Hong Kong, Taiwan, and Beijing for e-Learning in school education. Journal of Computers in Education, 4(1), 5-25. doi: 10.1007/s40692-016-0062-5

Küpçüoğlu, E. (2008). Bilişim teknolojilerinin temelleri: eğitimin ortaöğretimde interaktif yöntemlerle verilmesi [Fundamentals of information technologies: giving education with interactive methods in secondary education]. (Unpublished Doctoral Dissertation). Bahçeşehir University, İstanbul. 
Lim, C., \& Kye, B. (2019). Classroom Revolution through SMART Education in the Republic of Korea. Paris United Nations Educational, Scientific and Cultural Organization. Retrieved from: https://unesdoc.unesco.org/ark:/48223/pf0000366729

Luke, A., Freebody, P., Lau, S., \& Gopinathan, S. (2005). Towards research-based innovation and reform: Singapore schooling in transition. Asia Pacific Journal of Education, 25(1), 5-28. doi: 10.1080/02188790500032467

Mau, S. (1988). The research and diffusion of computer-assisted instruction. Bulletin of the National Institute of Educational Materials, 14, 277-286. Retrieved from: https://nie.edu.sg/about-us/publication/

Milli Eğitim Bakanlı̆̆ı (2005). 2006 Malî Yılı Bütçesine Illişkin Rapor [Report on the 2006 Fiscal Year Budget]. Ankara: Devlet Kitapları Müdürlüğü Basımevi.

Milli Eğitim Bakanlı̆̆ı (2011). PISA TÜRKIYE [PISA TURKEY], Yenilik ve Eğitim Teknolojileri Genel Müdürlügü. Retrieved from: http://pisa.meb.gov.tr/wpcontent/uploads/2013/07/PISA-kitab\%C4\%B1.pdf

Milli Eğitim Bakanlığı (2012). FATİH, Eğitimde Geleceğe Açılan Kapı [FATıH, the Gateway to the Future in Education]. Retrieved from: http://fatihprojesi.meb.gov.tr/

Milli Eğitim Bakanlığı (2020a). FATïH Projesi [Fatih Project]. Retrieved from: http://fatihprojesi.meb.gov.tr/

Milli Eğitim Bakanlığı (2020b.) Türkiye, Koronavirüs Salgınında Ulusal Çapta Uzaktan Eğitim Veren 2 Ülkeden Biri [Turkey, One of the 2 Countries Providing National Distance Education in the Coronavirus Outbreak]. Retrieved from: http://www.meb.gov.tr/turkiye-koronavirus-salgininda-ulusal-capta-uzaktanegitim-veren-2-ulkeden-biri/haber/20618/tr

Ministry of Education, Republic of China-Taiwan (1996). Ministry of Education Republic of China (Taiwan). Educational technology in Taiwan: Current and future, Ministry of Education in Taiwan, Taipei.

Ministry of Education, Republic of China-Taiwan (1998). Ministry of Education Republic of China (Taiwan). Educational technology curriculums, Ministry of Education in Taiwan, Taipei.

Naito, S., \& Hausman, B. (2005). Information and communications technology in Japan. A general overview of the current Japanese initiatives and trends in the area of ICT. Retrieved from: http://www.vinnova.se/upload/EPiStorePDF/vr-05-04.pdf

Organisation for Economic Co-operation and Development (2009). PISA 2009 assessment framework, $\quad$ Retrieved December 12, 2019, from http://www.oecd.org/dataoecd/11/40/44455820.pdf.

Organisation for Economic Co-operation and Development (2012a). PISA 2012 Results in Focus What 15-year-olds know and what they can do with what they know. Retrieved May 7, 2020 from https://www.oecd.org/pisa/keyfindings/pisa-2012-resultsoverview.pdf 
Organisation for Economic Co-operation and Development (2012b). Lessons from PISA for Japan, Strong Performers and Successful Reformers in Education, OECD Publishing. Retrieved from: http://dx.doi.org/10.1787/9789264118539-en

Organisation for Economic Co-operation and Development (2018). Education at a Glance 2018: OECD Indicators, Paris: OECD Publishing. Retrieved from: https://doi.org/10.1787/eag-2018-en.

Özdemir, S. (2010). To Err is Human, but to Persist İs Diabolical: Loss of Organizational Memory and E-Learning Projects. Computers \& Education, 55(1), 101-108. Retrieved from: https://www.journals.elsevier.com/computers-and-education

Özekicioğlu, H., \& Kılıç, C. (2017). Küresel ekonomi çağında Çin ve Hindistan [China and India in the era of the global economy]. Íktisat politikası araştırmaları dergisi, 4(2), 19-34. Retrieved from: https://dergipark.org.tr/en/download/article-file/330038

Özkan, M., Özkan, Y. Ö., \& Güvendir, M. A. (2019). Türkiye ve Singapur Okullarının Öğretmenlerin Mesleki Gelişimleri ve Öğrenimi Aksatan Öğretmen Davranışları Açısından İncelenmesi [An Investigation of Turkish and Singaporean Schools in Terms of Teachers' Professional Development and Teacher Behaviors that Disrupt Learning]. Eğitim ve Bilim, 44(198). Retrieved from: http://egitimvebilim.ted.org.tr/index.php/EB

Prais, S.J. (2004). Cautions on OECD's Recent Educational Survey (PISA): Rejoinder to OECD's Response. Oxford Review of Education, 30(4), 569-573. doi: 10.1080/0305498042000303017

Skryabin, M., Zhang, J., Liu, L., \& Zhang, D. (2015). How the ICT development level and usage influence student achievement in reading, mathematics, and science? Computers \& Education, 85, 49-58. doi: 10.1016/j.compedu.2015.02.004

Singapore Educational Technology Division (2008). 3rd Masterplan for ICT in education. Retrieved from: http://ictconnection.moe.edu.sg/cos/o.x?c=/ictconnection/pagetree\&func=view\&rid $=665$.

Singapore Educational Technology Division (2016). 4th Masterplan for ICT in education. Retrieved from: https://ictconnection.moe.edu.sg/Masterplan-4/vision-and-goals

Starateji ve Bütçe Başkanlığı (2019). Yedinici Beş Yıllık Kalkınma Planı (1996-2000) [Seventh Five-Year Development Plan (1996-2000)]. Retrieved from: https://www.sbb.gov.tr/wp-content/uploads/2018/11/Yedinci-Be\%C5\%9FY\%C4\%B1ll\%C4\%B1k-Kalk\%C4\%B1nma-Plan\%C4\%B1-19962000\%E2\%80\%8B.pdf

Şendurur, P., \& Arslan, S. (2017). Eğitimde teknoloji entegrasyonunu etkileyen faktörlerdeki değişim [Change in factors affecting technology integration in education]. Mehmet Akif Ersoy Üniversitesi Ĕ̆itim Fakültesi Dergisi, 43, 25-50. 
Tanrısevdi, F., \& Kıral, B. (2018). Çin ve Türk Eğitim Sisteminin Karşılaştırılması [Comparison of Chinese and Turkish Education System]. Çăgdaş Yönetim Bilimleri Dergisi, 5(3), 223-240. Retrieved from: https://dergipark.org.tr/tr/pub/cybd

Tayvan (15 Ocak, 2021). Vikipedi. Retrieved from: https://tr.wikipedia.org/wiki/Tayvan

Topu, F. B. (2010). Bilişim teknolojileri öğretmenlerinin okullarındaki rolleri, beklentiler ve karşılaşılan problemler: Erzurum ili örneği [Roles, expectations and problems faced by information technology teachers in their schools: The case of Erzurum province]. (Unpublished Masters' Thesis). Atatürk University, Erzurum.

Tygret, J.A. (2017). The influence of student teachers on student achievement: A case study of teacher perspectives. Teaching and Teacher Education: An International Journal of Research and Studies, 66(1), 117-126. doi: 10.1016/j.tate.2017.04.005

Usa, C. H. T., \& Twu, H. L. (2002). Educational technology in Taiwan. Educational Media International, 39(2), 153-164. doi: 10.1080/09523980210153444

UNESCO (2008). Strategy framework for promoting ICT literacy in the Asia-Pacific region, UNESCO Bangkok

Communication and Information Unit. Retrieved from: https://unesdoc.unesco.org/ark:/48223/pf0000162157_eng

Usluel, Y., Kuskaya-Mumcu, F., \& Demiraslan, Y. (2007). ICT in teaching-learning process: Teachers' views on the integration of ICT and on the perceived obstacles to this integration. Hacettepe University Journal of Education, 32, 164-179. Retrieved from: http://www.efdergi.hacettepe.edu.tr/

Uşun, S. (2004). Undergraduate Students Attitudes on the Use of Computers in Education. Turkish Online Journal of Educational Technology-TOJET, 3(2), 62-70. Retrieved from: http://www.tojet.net/

Wong, E. M., \& Li, S. C. (2006). Is ICT a lever for educational change? A study of the impact of ICT implementation on teaching and learning in Hong Kong. Informatics in Education, 5(2), 317-329. Retrieved from: https://infedu.vu.lt/journal/INFEDU

Wu, D. (2014). An introduction to ICT in education in China. R. Huang ve diğerleri. (Ed), ICT in Education in Global Context (s. 65-84) içinde. Berlin, Heidelberg: Springer.

Vallance, M. (2008). Beyond policy: Strategic actions to support ICT integration in Japanese schools. Australasian Journal of Educational Technology, 24(3). doi: 10.14742/ajet.1209

Vogt, F., \& Rogalla, M. (2009). Developing adaptive teaching competency through coaching. Teaching and Teacher Education, 25(8), 1051-1060. doi: 10.1016/j.tate.2009.04.002

Yardımcıoğlu, F., \& T. Gürdal (2012). Türkiye'de Eğitimin Niteliğinin OECD ve AB Ülkeleri İle Karşılaştırmalı Bir Analizi [A Comparative Analysis of the Quality of 
Education in Turkey with OECD and EU Countries]. Finans Politik ve Ekonomik Yorumlar, 49(570), 35-50. Retrieved from: http://www.ekonomikyorumlar.com.tr/

Yıldırım, A., \& Şimşek, H. (2008). Sosyal Bilimlerde Nitel Araştırma Yöntemleri [Qualitative research methods in the social sciences] (6th ed). Ankara: Seçkin Yayıncilık.

Yıldız, T. (2008). Öğretmenler İçin Interaktif Test Geliştirme Platformu [Interactive Test Development Platform for Teachers]. (Unpublished Masters' Thesis). Bahçeşehir University, İstanbul.

Yiğit, A. M. (2013). Teachers' attitudes towards the "dyned" in primary education in Turkey. Journal of Educational \& Instructional Studies in the World, 3(3), 56-65. Retrieved from: http://wjeis.org

Yurttaş Kumlu, G. D. (2018). Türkiye'de PISA uygulamasına katılan öğrencilerin bilgi ve iletişim teknolojilerine erişimlerinin PISA sonuçlarını yordama düzeyleri [The level of predicting the PISA results of the students' access to information and communication technologies participating in the PISA application in Turkey.]. (Unpublished Masters' Thesis). Hacettepe Üniversitesi, Ankara.

Zhu, Z., Gu, X, Collis, B., \& Moonen, J. (2011). Use of ICT in Chinese schools: Striving for educational quality and equality. Educational Technology, 51(3), 32-37. Retrieved from: https://www.jstor.org/ 
Ethics approval was obtained from the Ethics Committee of Trabzon University with a letter dated 27.11.2020 numbered 81614018-000-E.533.

\section{Statement of Contribution of Researchers to the Article:}

1st author contribution rate: $50 \%$

2nd author contribution rate: $50 \%$

\section{Conflict of Interest Statement:}

There is no conflict of interest.

Statement of Financial Support or Acknowledgment:

No financial support was received from any institution for this study. 


\title{
PISA'da Başarı Gösteren Asya-Pasifik Ülkelerinin K-12 Düzeyindeki Eğitiminden Alınabilecek Dersler: BİT Entegrasyonu Boyutu*
}

\section{Semra Fiș ERÜMITT**}

\author{
Esra KELEŞ***
}

\begin{abstract}
Öz. Bu çalışmada, PISA sınavlarında ilk 10 içerisine giren Asya-Pasifik bölgesindeki ülkelerin Bilgi ve İletişim Teknolojilerini eğitim ortamlarına nasıl entegre ettikleri araştırılmıştır. PISA, OECD tarafından 3 yılda bir düzenlenen ve 15 yaş grubundaki öğrencilerin matematik, fen bilimleri ve okuma becerilerinin değerlendirildiği bir programdır. 2000 yılında yapılmaya başlanan PISA'da zamanla ilk 10 içerisine giren Asya-Pasifik bölgesindeki ülkelerin arttığı görülmektedir. Günümüzde ülkelerin eğitim sistemlerinin dayandığı temel noktalardan birisi de eğitim teknolojileri ve bunların öğretim süreçlerine yansımaları olmuștur. Bu nedenle çalıșmada, AsyaPasifik bölgesindeki ülkelerin bilgi ve iletişim teknolojilerine yönelik entegrasyon çalışmaları ve bu çalışmaların PISA sınavlarında öğrenci başarısına etkileri araștırılmıştır. Çalışmada, döküman analizi yöntemi kullanılmıştır. Bu kapsamda; PISA sonuçları ve raporları, OECD raporları, ülkelerin BİT entegrasyonuyla ilgili yapılmış projeleri, PISA ile ilgili yapılmış çalıșmalar incelenmiştir. Çalışma sonunda, ülkelerin BİT entegrasyonuna yönelik çalıșmaları karșılaștırılarak, BİT entegrasyonunda ön plana çıkan uygulamaları belirlenmiştir. Ayrıca ülkelerin BíT entegrasyon çalışmaları ile Türkiye'de yapılan uygulamalar kıyaslanarak bu çalışmaların PISA sonuçlarına etkisiyle ilgili çıkarımlarda bulunulmuştur.
\end{abstract}

Anahtar Kelimeler: Asya-Pasifik ülkeleri, PISA, BİT entegrasyonu, Eğitim politikaları

\footnotetext{
* Bu çalışma için etik kurul izni 27.11.2020 tarih ve 81614018-000-E.533 sayılı Trabzon Üniversitesi Rektörlüğü Etik Kurulu'ndan alınmıștır.

** Orcid ID: https://orcid.org/0000-0002-7161-8903, Dr. Karadeniz Teknik Üniversitesi, Türkiye, semra727@gmail.com

*** Orcid ID: https://orcid.org/0000-0002-8924-1657, Doç., Dr., Trabzon Üniversitesi, Türkiye, esrakeles@trabzon.edu.tr
}

Fiș Erümit, S., \& Keleș, E. (2021). Lessons to be Taken from K-12 Education Level of Asia-Pacific Countries that are Successful in PISA: ICT Integration Dimension. Sakarya University Journal of Education, 11(3), 452-481. doi: https://doi.org/10.19126/suje.940080 


\section{GİRIŞ}

Uluslararası Öğrenci Değerlendirme Programı (Programme for International Student Assesment) olan PISA, Ekonomik İş birliği ve Kalkınma Örgütü (OECD) tarafından üçer yıllık dönemler hâlinde gerçekleştirilen, 15 yaş grubundaki öğrencilerin bilgi ve becerilerini değerlendirmeyi amaçlayan bir programdır (MEB, 2011). Program kapsamında öğrencilerin değerlendirilmesi için kullanılan test ve anketlerin hazırlanması, sonuçların değerlendirilmesi ve raporların hazırlanması gibi işlemler gerçekleştirilmektedir. PISA sonuçları ile ülkeler kendi eğitim sistemlerini değerlendirme, diğer ülkelerin eğitim sistemleriyle klyaslama, eğitim sistemindeki güçlü ve zayıf yönlerini belirleme firsatı bulmaktadır. Ayrıca ülkeler eğitim politikalarını, öğretim programlarını, öğretmen yeterliliklerini, araç-gereç ve materyal kullanımı gibi unsurları diğer ülkelerle karşılaştırma imkanı bulmaktadır. Ülkelerin bu değerlendirmeleri yapması hem eğitim politikalarının gözden geçirilmesi hem de eğitim sistemindeki eksiklerin fark edilip bu eksikliklerin giderilmesi konusunda uygulayıcılara fikir sağlamaktadır (Bakioğlu ve Baltacı, 2019).

2000 yılında yapılmaya başlanan PISA sınavına, OECD’ye üye olan ve olmayan ülkeler katılabilmektedir. Her yıl katılımcı ülke sayısının arttığı sınava 2009 yılından sonra Asya-Pasifik bölgesindeki ülkelerin, özellikle Çin'e bağlı eyaletlerin katılımında artış görülmüştür. Katıldıkları yıllarda büyük başarı göstermesi nedeniyle dikkatler bu ülkelerin eğitim sistemleri üzerine çekilmiştir. Günümüzde eğitim teknolojileri eğitim ortamlarında yoğun olarak kullanıldığı için eğitim sistemlerinin de bu teknolojilerden ayrı düşünülmesi mümkün değildir. Hem müfredatlar içerisinde hem de sinıf ortamlarında farklı teknoloji, araç-gereç ve uygulamalar kullanılmaktadır. Bu nedenle PISA sınavında başarı gösteren Asya-Pasifik bölgesindeki ülkelerin eğitim sistemleri kadar Bilgi ve İletişim Teknolojilerinin (BİT) eğitim sürecine entegrasyonunun önem kazandı̆̆ görülmektedir.

\section{PISA Programının Kapsamı}

PISA farklı ülkelerdeki öğrencilerin okuma, matematik ve fen alanlarındaki bilgi ve becerilerini ölçmenin yanı sıra günlük yaşantılarında karşılaşabilecekleri sorunları çözümleyebilme becerilerini de belirlemeyi amaçlamaktadır (Prais, 2004). PISA programının amacı, öğrencilerin okuma, matematik ve fen alanlarındaki bilgilerini ölçmek değildir. PISA, öğrencilerin sahip olduğu bilgileri analiz ederek bu bilgileri kullanabilme becerilerini değerlendirmektedir (Aşkar ve Olkun, 2005; Aydoğdu İskenderoğlu ve Baki, 2011). Ayrıca PISA programı kapsamında öğrencilere, velilere ve okul yönetimine anketler uygulanarak öğrencilerin başarısının ve başarısızlığının sebeplerini ortaya çıkaracak analizler yapılmaktadır (OECD, 2012a). PISA için hazırlanan sınav; matematik, fen ve okuma becerilerine yönelik hazırlanan sorulardan yapılmaktadır. 2003 yılından beri problem çözme becerileriyle ilgili sorular da sorulmaktadır. Problem çözme becerilerinin değerlendirilmesinin amacı; bireysel problem çözme sürecindeki bilişsel becerilerin değerlendirilmesidir. Bunun için öğrencilere; keşfetme ve anlama, formüle etme, planlama ve uygulama, kontrol etme ve 
yansıtma süreçlerinin değerlendirilmesini sağlayan problemler sorulmaktadır (MEB, 2011). PISA sınavında; çoktan seçmeli, açık uçlu, kapalı uçlu gibi farklı soru çeşitleri kullanılmaktadır. PISA sınavına öğrenciler tabakalandırma işlemi yapılarak ve tesadüfi yöntemle seçilmektedir. İlgili ülkedeki coğrafi bölgelere göre öncelikle tabakalandırma işlemi yapılır, ardından bu bölgelerdeki okullardan seçkisiz yöntemle seçim yapılır ve bu okullarda kayıtlı olan 15 yaş grubundaki öğrenciler tesadüfi olarak seçilir.

İlk PISA değerlendirmesi 2000 yllında 28'i OECD ülkesi olan 32 ülke ile gerçekleştirilmiştir. 2018'deki PISA değerlendirmesine ise 37'si OECD ülkesi olan 72 ülke katılmıştır (Tablo 1). Katılımcı ülke sayısındaki artışı, ülkelerin PISA sınavını ne derece önemsediğinin bir göstergesi olarak değerlendirmek mümkündür.

\section{Tablo 1.}

2000-2018 Yılları Arasında Yapılan PISA Sonuçlarına Göre İlk 10 İçerisinde Yer Alan Ülkeler

\begin{tabular}{|c|c|c|c|c|c|c|c|}
\hline & 2000 & 2003 & 2006 & 2009 & 2012 & 2015 & 2018 \\
\hline 1 & $\begin{array}{l}\text { Finlandi } \\
\text { уа }\end{array}$ & $\begin{array}{l}\text { Hong-Kong } \\
\text { (Çin) }\end{array}$ & Finlandiya & $\begin{array}{l}\text { Şangay } \\
\text { (Çin) }\end{array}$ & $\begin{array}{l}\text { Şangay } \\
\text { (Çin) }\end{array}$ & Singapur & $\begin{array}{l}\text { B-S-J-Z } \\
\text { (Çin) }\end{array}$ \\
\hline 2 & Kanada & Finlandiya & $\begin{array}{l}\text { Hong-Kong } \\
\text { (Çin) }\end{array}$ & $\begin{array}{l}\text { Güney } \\
\text { Kore }\end{array}$ & Singapur & Japan & Singapur \\
\hline 3 & $\begin{array}{l}\text { Yeni } \\
\text { Zelanda }\end{array}$ & Güney Kore & Kanada & Finlandiya & $\begin{array}{l}\text { Hong-Kong } \\
\text { (Çin) }\end{array}$ & Estonya & $\begin{array}{l}\text { Makao } \\
\text { (Çin) }\end{array}$ \\
\hline 4 & $\begin{array}{l}\text { Avustral } \\
\text { ya }\end{array}$ & Hollanda & $\begin{array}{l}\text { Çin Taipei } \\
\text { (Tayvan) }\end{array}$ & $\begin{array}{l}\text { Hong- } \\
\text { Kong (Çin) }\end{array}$ & $\begin{array}{l}\text { Çin Taipei } \\
\text { (Tayvan) }\end{array}$ & $\begin{array}{l}\text { Çin Taipei } \\
\text { (Tayvan) }\end{array}$ & $\begin{array}{l}\text { Hong-Kong } \\
\text { (Çin) }\end{array}$ \\
\hline 5 & İrlanda & Lihtenștayn & Estonya & Singapur & Güney Kore & Finlandiya & Estonya \\
\hline 6 & $\begin{array}{l}\text { Güney } \\
\text { Kore }\end{array}$ & Japonya & Japonya & Kanada & Makao (Çin) & $\begin{array}{l}\text { Makao } \\
\text { (Çin) }\end{array}$ & Kanada \\
\hline 7 & $\begin{array}{l}\text { Birleșik } \\
\text { Krallık }\end{array}$ & Kanada & Yeni Zelanda & $\begin{array}{l}\text { Yeni } \\
\text { Zelanda }\end{array}$ & Japonya & Kanada & Finlandiya \\
\hline 8 & Japonya & Belçika & Avustralya & Japonya & Lihtenștayn & Vietnam & İrlanda \\
\hline 9 & İsveç & $\begin{array}{l}\text { Makao } \\
\text { (Çin) }\end{array}$ & Hollanda & Avustralya & İsviçre & $\begin{array}{l}\text { Hong Kong } \\
\text { (Çin) }\end{array}$ & $\begin{array}{l}\text { Güney } \\
\text { Kore }\end{array}$ \\
\hline 10 & $\begin{array}{l}\text { Avustur } \\
\text { уа }\end{array}$ & İsviçre & Lihtenștayn & Hollanda & Hollanda & $\begin{array}{l}\text { B-S-J-G } \\
\text { (Çin) }\end{array}$ & Polonya \\
\hline 11 & - & $\begin{array}{l}\text { Türkiye } \\
\text { (35) }\end{array}$ & Türkiye (43) & $\begin{array}{l}\text { Türkiye } \\
\text { (41) }\end{array}$ & $\begin{array}{l}\text { Türkiye } \\
\text { (44) }\end{array}$ & $\begin{array}{l}\text { Türkiye } \\
\text { (52) }\end{array}$ & $\begin{array}{l}\text { Türkiye } \\
(40)\end{array}$ \\
\hline Ö.S. & 265.000 & 275.000 & 400.000 & 475.460 & 510000 & 540000 & 600000 \\
\hline KÜS/ & 32 & 41 & 57 & 65 & 65 & 72 & 79 \\
\hline oÜÜS & $\begin{array}{l}(28 \\
\text { OECD) }\end{array}$ & (30 OECD) & (30 OECD) & (33 OECD) & (34 OECD) & (35 OECD) & (37 OECD) \\
\hline
\end{tabular}

*Renkli olarak seçilen ülkeler Asya-Pasifik bölgesindeki ülkelerdir.

** Ö.S.: Öğrenci Sayısı KÜS/OÜÜS: Katılan Ülke Sayısı/OECD’ye üye ülke sayısı 


\section{BİT'in Eğitime Entegrasyonu}

Son yıllarda Asya-Pasifik ülkelerinin ekonomik kalkınması ve PISA sinavlarındaki başarıları, dikkatleri bu ülkelerin eğitim sistemlerine ve uygulamalarına çekmiştir (Bakioğlu ve Baltacl, 2019). Günümüz teknolojisinin geldiği durum ve hayatımıza yansımaları düşünüldüğünde; ülkelerin eğitim sistemlerindeki temel yapı taşlarından birisi de şüphesiz eğitim teknolojileri ve bu teknolojilerin öğretim süreçlerine yansımaları olmuştur. Bu nedenle ülkelerin BİT teknolojilerinin kullanılmasına yönelik eğitim politikaları önemli bir konu haline gelmiştir. Ulusal BİT gelişim düzeyinin; PISA, TIMMS gibi uluslararası sınavlarda öğrencilerin akademik başarısını pozitif olarak etkilediği belirtilmektedir (Skryabin, Zhang, Liu ve Zhang, 2015). Tablo 1'deki sıralamalar incelendiğinde 2009 yılı ve sonrasındaki PISA sıralamasında, Asya-Pasifik bölgesindeki ülkelerin ön plana çıktığı, Türkiye'nin başarısının ise beklenen seviyeden oldukça düşük olduğu açıktır. Türkiye'nin özellikle 2011 yılından itibaren FATİH projesi ile eğitim teknolojileri alanında yaptığı çalışmalar düşünüldüğünde BİT alanındaki gelişmelerin PISA gibi çalışmalardaki başarıyı pozitif yönde etkileme açısından zayıf kaldığı ya da istenilen etkiyi sağlayamadığı görülmektedir. Bu nedenle çalışmada, AsyaPasifik bölgesindeki ülkelerin BİT entegrasyonu çalışmalarının PISA sınavlarındaki öğrenci başarısına etkilerinin araştırılması ve yapılan çalışmaların Türkiye'de gerçekleştirilen çalışmalarla karşılaştırılması amaçlanmıştır. Bu amaçla çalışmada PISA sınavlarında ilk 10 içerisine giren Asya-Pasifik bölgesindeki ülkelerin (Japonya, Güney Kore, Hong-Kong-Çin, Singapur, Çin, Tayvan-Tapei) BİT’i eğitim ortamlarına nasıl entegre ettikleri araştırılmıştır. Ayrıca Türkiye'de yapılan BİT entegrasyon çalışmaları da araştırılarak ülkemizdeki çalışmaların Asya-Pasifik bölgesindeki ülkelerde yapılan çalışmalarla karşılaştırılması hedeflenmiştir. Böylece Türkiye'nin eğitimdeki başarısının artırılmasına yönelik örnek alınabilecek çalışmaların belirlenmesine katkı sağlanacaktır. Ayrıca bu çalışmanın Asya-Pasifik bölgesindeki ülkelerin PISA sınavlarındaki başarısının nedenlerine ışı tutacağı ve bu ülkelerdeki uygulamaların Türkiye'deki uygulamalarla karşılaştırılmasına yardımcı olacağı düşünülmektedir. Buna göre çalışmanın alt araştırma soruları şöyledir:

1. Asya-Pasifik ülkelerinde yer alan K12 düzeyindeki okullarda Bilgi ve İletişim Teknolojilerinin eğitim ortamlarına entegrasyonu için hangi çalışmalar yapılmıştır?

2. Türkiye'de K12 düzeyindeki okullarda BİT entegrasyonuyla ilgili yapılan çalışmalar nelerdir?

\section{YÖNTEM}

Bu bölümde araştırma yöntemi, çalışma grubu ve veri toplama aracı ile ilgili bilgiler sirasıyla sunulmuştur.

\section{Araştırma Modeli}

Çalışmada nitel araştırma yöntemlerinden doküman analizi yöntemi kullanılmıştır. Doküman analizi, araştırılan konu hakkında bilgi içeren yazılı kaynakların analizini 
kapsamaktadır (Yıldırım ve Şimşek, 2008). Doküman analizi ile basılı kaynaklar, web ortamındaki kaynak, belge ve bilgilerin taraması yapılmaktadır (Bowen, 2009). PISA sınavlarında ilk 10 içerisine giren Asya-Pasifik bölgesindeki ülkelerin BİT entegrasyon çalışmaları analiz edilerek var olan durumlarının yorumlanması amacıyla doküman analizi yöntemi kullanılmıştır. Bu kapsamda ülkelerin eğitimde BİT entegrasyon çalışmaları belirlenen anahtar kelimelerle aratılmış, elde edilen dokümanların analizi yapılarak, bulguların betimleyici şekilde değerlendirmesi yapılmıştır. Çalışmada; OECD tarafından 2000-2019 yılları arasında yayınlanan PISA sonuçları ve raporları, ülkelerin Milli Eğitim Bakanlıklarındaki müfredatları ve BİT entegrasyon çalışmaları, araştırma raporları ve BİT alanında yapılmış akademik çalışmalar incelenmiştir. Bu çalışma için etik kurul izni 27.11.2020 tarih ve 81614018-000-E.533 sayll Trabzon Üniversitesi Rektörlüğü Etik Kurulu'ndan alınmıştır.

\section{Örneklem}

Çalışmanın örneklemini, 2000-2018 yılları arasında yapılan yedi PISA sınavında ilk on içerisine giren Asya-Pasifik bölgesindeki altı ülke ve Türkiye oluşturmaktadır. PISA'da ilk on içerisine giren Asya-Pasifik bölgesindeki ülkeler; Japonya, Güney Kore, Hong-Kong (Çin), Singapur, Tayvan-Tapei, Vietnam, Shanghai (Çin), Macau (Çin), Beijing, Shanghai, Jiangsu, Guangdong (Çin) ve Beijing, Shanghai Jiangsu, Zhejiang (Çin)'dir. PISA'da 20002018 yılları arasında ilk on içerisine giren ülkeler ve çalışmada incelenen ülkeler Şekil 1'de açıklanmıştır.

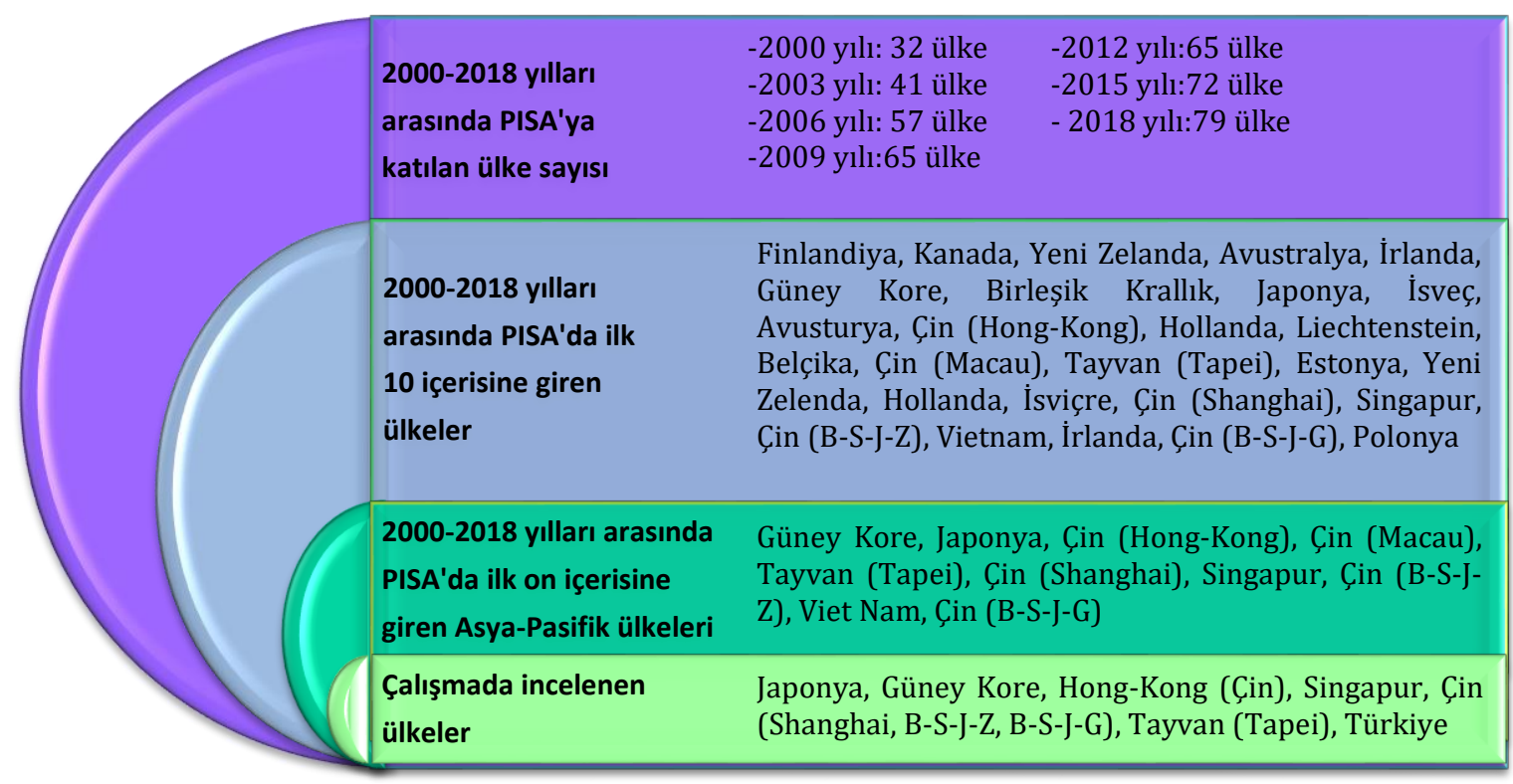

Şekil 1. Örneklem

$\mathrm{Bu}$ ülkelerin nüfusu, öğrenci başına yapılan eğitim harcaması, okulda bilgisayar başına düşen öğrenci sayısı, okulda bilgisayar kullanabilen öğrenci yüzdesi ve ödev yapmak için interneti kullanan öğrenci sayılarında farklılıklar olduğu görülmektedir (Tablo 2). Ayrıca 
katılım sağlayan bağımsız ülkeler bulunduğu gibi, yönetim olarak Çin'e bağlı özerk yönetim bölgeleri (Hong Kong, Macau) ya da Çin eyaleti (Shanghai, B-S-J-G ve B-S-J-Z) olarak sınava katılan bölgeler bulunmaktadır.

Tablo 2 .

PISA'ya Katılan Ülkelerin/Eyaletlerin Özellikleri

\begin{tabular}{|c|c|c|c|c|c|c|}
\hline Ülke & $\begin{array}{l}\text { PISA'da ilk } \\
10 \\
\text { siralamasına } \\
\text { girme sayısı }\end{array}$ & Nüfus & $\begin{array}{l}\text { Öğrenci } \\
\text { Başına } \\
\text { Yapılan } \\
\text { Eğitim } \\
\text { Harcaması } \\
(\$)\end{array}$ & $\begin{array}{l}\text { Okulda } \\
\text { bilgisayar } \\
\text { başına düșen } \\
\text { ortalama } \\
\text { öğrenci sayısı }\end{array}$ & $\begin{array}{l}\text { Okulda } \\
\text { bilgisayar } \\
\text { kullanan } \\
\text { öğrenci (\%) }\end{array}$ & $\begin{array}{l}\text { Haftada en az } \\
\text { bir kez ödevi } \\
\text { için internetti } \\
\text { kullanan } \\
\text { öğrenci (\%) }\end{array}$ \\
\hline Japonya & 6 & $126,573.000$ & 12.120 & 3,6 & 59,2 & 11,3 \\
\hline Singapur & 5 & $5,638.676$ & 5010 & 2 & 69,9 & 30,4 \\
\hline $\begin{array}{l}\text { Güney } \\
\text { Kore }\end{array}$ & 5 & $25,155.000$ & 11.143 & 5,3 & 41,9 & 11 \\
\hline Vietnam & 4 & $95,540.395$ & 398 & 8,6 & Bilgi yok & Bilgi yok \\
\hline $\begin{array}{l}\text { Çin } \\
\text { (Shangai, } \\
\text { B-S-J-G, }\end{array}$ & 4 & $\begin{array}{l}1 \\
393.000 .000\end{array}$ & 11.069 & 2,9 & 38,3 & 9,7 \\
\hline $\begin{array}{l}\text { *Hong } \\
\text { Kong (Çin) }\end{array}$ & 4 & $7,436.154$ & 5710 & 2,2 & 83,8 & 22,7 \\
\hline $\begin{array}{l}\text { *Macau } \\
\text { (Çin) }\end{array}$ & 3 & 588.000 & 3874 & 1,3 & 87,6 & 26,7 \\
\hline $\begin{array}{l}\text { Tayvan- } \\
\text { Taipe }\end{array}$ & 1 & $23,78.000$ & 5893 & 5,8 & 78,8 & 28,6 \\
\hline Türkiye & - & $82,319.724$ & 4.652 & 44,9 & 48,7 & 28 \\
\hline $\begin{array}{l}\text { OECD } \\
\text { Ortalaması }\end{array}$ & & - & 10.520 & 4,7 & 72 & 41,9 \\
\hline
\end{tabular}

(Kaynak: OECD, 2018; Aydın, Selvitopu, ve Kaya, 2018). * Çin'e bağlı özel yönetim bölgesi

PISA sınavlarında Çin'e bağlı eyalet ve bölgelerin başarıları dikkat çekmektedir. Çin PISA'ya 2009 ve 2012 yılında Shanghai eyaleti ile katılmıştır. 2015 yılında B-S-J-G (Beijing, Shanghai, Jiangsu, Guangdong) adıyla 4 eyaletten seçilen öğrencilerle, 2018 yılında ise B-S-J-Z (Beijing, Shanghai Jiangsu, Zhejiang) eyaletlerinden seçilen öğrencilerle katılım göstermiştir. Çin sınavlara ülke adıyla katılmamış, öğrenci seçimi yapılan eyaletlerin ismiyle katılmıştır. Bu eyaletler de Çin eğitim bakanlığına bağlı olduğu için, eyaletlerin BİT entegrasyon çalışmalarını araştırmak için Çin'in yaptığı çalışmalar incelenmiştir. Hong-Kong ve Macau dış işlerinde Çin'e bağlı özerk bölgelerdir. 
Bu bölgeler "Tek Ülke İki Ayrı İdari Sistem” adıyla yönetilmektedir (OECD, 2012). HongKong ve Macau'nun özerk yönetimleri ve kendi eğitim sistemleri mevcuttur. Tayvan ise bugün dünyada ancak 23 ülke tarafından tanınan bağımsız bir devlettir. Çin, Tayvan'ın bağımsızlığını tanımadığından bu ülke birçok organizasyona başkent Taipe adıyla katılmaktadır (Tayvan, 2021). Hong-Kong ve Tayvan'ın da ayrı bir yönetimi ve eğitim sistemi olması nedeniyle BİT alanındaki gelişmeleri ayrı incelenmiştir.

\section{Verilerin Toplanması}

Belirlenen ülkelerin BİT entegrasyon çalışmaları ile ilgili alanyazın tarama sürecinde; ISI Web of Science, ERIC ve Google Scholar kullanılmıştır. Belirtilen veri tabanları; yaygın kullanımı, ilgili yayınların fazlalığı ve farklı veri tabanlarından kaynaklara erişim nedeniyle tercih edilmiştir. Bu tarama sonucunda ulaşılan kaynakların içerik analizi yapılmıştır. Makale tarama sürecinde hem Türkçe hem de İngilizce anahtar kelimeler kullanılmıştır. Kullanılan anahtar kelimeler; "educational technology", "information and communication technologies", "ICT integration", "eğitim teknolojileri”, "bilgi ve iletişim teknolojileri", "BİT entagrasyonu" olmuştur. Seçilen kaynakların referansları da incelenerek arama sonucunda çıkmayan ve araştırmaya uygun çalışmalar da taranmıştır. Yapılan tarama sonucunda 140 adet makaleye ulaşılmıştır. Konu ile yeterince ilgisi olmayan ve yeterli veri elde edilemeyen çalışmalar elenerek 58 adet makaleden veri elde edilmiştir. Ayrıca OECD ve PISA raporları, ülkelerin eğitim bakanlıklarında yer alan öğretim programları ve raporlara da kurumların web sitelerinden ulaşılmıştır. Alanyazın taraması sonucunda çalışmada kullanılan kaynaklar şöyledir:

- PISA sonuçları ve raporları

- PISA ile ilgili yapılmış çalışmalar

- OECD raporları

- BİT entegrasyon çalışmaları

- Ülkelerin eğitim sistemleri ve BİT entegrasyonuyla ilgili kitaplar

- Ülkelerin eğitim sistemleri ve BİT alanında hazırladığı raporlar

- Ülkelerin eğitim sistemleri ile ilgili yapılmış akademik çalışmalar ve raporlar

- Ülkelerin öğretim programları

\section{Verilerin Analizi}

Çalışmadaki veriler doküman analizi tekniğiyle elde edilmiştir. Araştırma yapılan dokümanlar araştırma soruları çerçevesinde taranmıştır. İncelenen dokümanlar içerisinde BİT politikaları ve entegrasyon çalışmaları analiz edilmiştir.

Ülkelerde BİT politikaları ve BİT'in eğitim ortamlarına entegrasyonuna yönelik yapılan çalışmalara ait kaynaklar;

- Hangi yıllarda BİT entegrasyon çalışmalarının yoğun olarak uygulandığı

- BİT politikalarıyla ilgili yapılan revizyonlar 
- BİT entegrasyonuna yönelik yapılan projeler ve eğitim ortamına yansımaları

- BİT entegrasyonu için yapılan teknik, alt yapı ve yazılım yatırımlarına yönelik konular

temel alınarak analiz edilmiştir.

\section{Sinırlılıklar}

Çalışmada incelenen ülkelerin tümünün BíT entegrasyon çalışmalarına ulaşılamamıştır. Yeterli bilgi elde edilemeyen ülkeler Macau ve Vietnam olmuştur. Bu ülkelerin Eğitim Bakanlıklarına ait web sitelerinde eğitim müfredatlarına ya da politikalarına yönelik kaynaklara ulaşılamamıştır. Bu ülkelerde konuyla ilgili yapılan az sayıda akademik çalışmaya ulaşılmıştır. Ancak ulaşılan bazı kaynaklar da ülkelerin kendi dillerinde olduğu için çevirileri yapılamamıştır. Bu nedenle Macau ve Vietnam, PISA'da üst sıralarda yer alsa da çalışma içerisine dahil edilememiştir.

\section{BULGULAR}

Çalışmadaki bulgular araştırma sorularına göre verilmiştir. Birinci araştırma sorusu için 6 ülkede (veya eyalet) yapılan BíT entegrasyon çalışmaları ve bu çalışmaların sonuçları verilmiştir. Bulgular, ülkelerin PISA'daki sıralamasına göre verilmektedir. İkinci araştırma sorusuna yönelik olarak Türkiye'de yapılan BìT entegrasyon çalışmaları sunulmuştur.

\section{Asya-Pasifik Ülkelerinde K12 Düzeyindeki Okullarda Yapılan BíT Entegrasyon Çalışmaları}

\section{Japonya}

İleri düzey teknolojik uygulamalara sahip ülkelerden birisi olan Japonya PISA'da oldukça başarılı sonuçlar elde etmiştir. Ancak Japonya, eğitim politikalarında reform yapmakta yavaș davranan ülkelerden olmuştur (Vallance, 2008). Japonya'daki eğitim ortamlarında hem teknoloji kullanımı hem de BìT'in eğitim süreçleri içerisine entegrasyonu yavaş ilerlemiştir (UNESCO, 2008). Özellikle Japonya'daki öğretmenleri ve öğrencileri hedefleyen anlamlı bir teknoloji politikasının olmaması nedeniyle, eğitimcilerin okul müfredatında dijital temelli öğrenme süreçlerini en iyi nasıl gerçekleștirecekleri konusunda az çalışma yapılmıştır. Ancak 2000'li yılların başında Japonya'da BíT temelli eğitim politikalarının uygulanması için girişimlerde bulunulmuştur. Bunun için 1999 yılında, 2005 yılına kadar tüm ilk ve orta dereceli okullarda bilgisayarların öğretimde kullanılması için Eğitimde Bilgi Teknolojileri Projesi (ITEP) başlatılmıştır (Vallance, 2008). Bu proje ile 2005 yılına kadar tüm sınıflara bilgisayar ve internet erişimi sağlanmıştır. Bu kapsamda öğretmenlerin bilgisayar becerilerini geliştirmeleri ve derslerinde bilgisayar kullanmalarını sağlamak için, bilgisayar kullanımına yönelik video ve görseller hazırlanmıştır. Ayrıca ulusal boyutta, eğitim materyalleri sitesi oluşturulmuştur. 2001 yılında, Japonya'yı 2005 yılına kadar dünyanın en gelişmiş bilişim teknolojisi ülkesi yapmak için strateji merkezi kurulmuştur (Naito ve Hausman, 2005). 
Bu merkezde ilkokul ve ortaokulların BíT kullanımına yönelik planlanan çalışmalar şu şekilde olmuştur:

- 2005 yılına kadar tüm okullara hızlı internet bağlantısının sağlanması

- 2005 yılına kadar tüm sınıflara internet bağlantısının yapılması

- Bilgisayar sınıflarında her öğrenciye 1 bilgisayar sağlanması

- Gerekli bilişim teknolojileri uygulamalarının satın alınması

Japonya'da öğrenci ve öğretmenlerin okulda ICT kaynaklarına erişimi kısa zamanda tamamlanmıştır. Okullarda internet bağlantısı sağlanmıştır. Öğretmenlerin büyük bir kısmı bilgisayarı kullanma becerisine sahip olmuştur (UNESCO, 2008). Ancak Japonya'da öğretmen ve öğrencileri hedefleyen teknoloji politikalarının yaygın olmaması nedeniyle, okul müfredatına BİT teknolojilerinin entegre edildiği çok fazla uygulama bulunmamaktadır. OECD’nin 2012 raporunda Japonya'nın, PISA'da yüksek başarı gösteren ama evde ve okulda bilgisayar ve interneti eğitim amacıyla az kullanan bir ülke olduğu belirtilmiştir (OECD, 2012b). Japonya'da son yıllarda sınıflarda kullanılan akıllı tahtalar ve tabletlerle teknoloji derslere entegre edilmeye başlanmıştır (Kanemune, Shirai ve Tanı, 2017).

\section{Güney Kore}

Güney Kore'nin eğitimde BİT kullanım amacı; bilim ve teknolojide rekabeti güçlendirmek, dünya çapındaki ekonomik, toplumsal, bilimsel ve eğitsel değişimleri yakalamak olarak belirlenmiştir. 1980'lerde başlayan BİT'in eğitime entegrasyonu çalışmaları 1995'te Eğitimi İyileştirme Komitesi tarafından hazırlanan "Eğitimin Yenilenmesi Planı" ile devam etmiştir. Bu kapsamda Güney Kore'de 2000 yılından itibaren tüm sınıflarda bilgisayar kullanımı başlamıştır. Eğitimden sorumlu olan; Eğitim, Bilim ve Teknoloji Bakanlığı, BİT kullanımını artırmak için 2010 yılından bu yana çalışmalarını artırmıştır. Bu amaçla "SMART Education" adında bir eğitim planı açıklanmıştır. SMART programının temel amacı; tüm okul müfredatlarının ve eğitim kaynaklarının 2015 yılına kadar dijitalleştirilmesidir (Grzybowski, 2013). SMART eğitim programının hedefleri şunlardır:

- Dijital ders kitaplarının ve çevrimiçi değerlendirme sistemlerinin geliştirilmesi

- Öğrencilere açık web ortamlarının oluşturulması

- Eğitim kaynaklarının internet ortamında depolanması

- Eğitim kaynaklarının güvenli ve hızlı bir şekilde kullanımını

BİT kullanımının, Güney Kore'nin kalkınmadaki başarısının anahtarlarından birisi olarak görülmesi nedeniyle, Güney Kore eğitim sisteminde teknoloji kullanımı ve bunu eğitim sistemi içerisine entegre edebilme ön planda tutulmuştur. Güney Kore, eğitimde yaptığı bu çalışmalar ile Güneydoğu Asya'nın eğitim merkezi olmayı hedeflemiş ve proje ile büyük yol kat etmiştir (Kim, Cho ve Lee, 2016). SMART projesi kapsamında öğrencilere tablet, akıllı telefon ve bilgisayar sağlanmıştır. Güney Kore hükümeti, 2015 yılına kadar tüm orta ve lise seviyesindeki okullara dizüstü bilgisayar ve ekonomik durumu sıkıntılı 
öğrenciler için ücretsiz tablet verilmesini planlamıştır. Tablet ve bilgisayarlar, öğrencilere sadece elektronik kitapların kullanımını sağlamamış aynı zamanda diğer kaynaklara erişim imkanı da sağlamıştır. Çünkü akıllı telefonlar ve dizüstü bilgisayarlar Güney Kore'de pedagojik bir eğitim aracı olarak kabul edilmektedir. Ayrıca tüm okullara kablosuz internet sağlanmış ve BİT'in eğitime entegrasyonu konusunda personel eğitimlerine büyük önem verilmiştir (Jang, 2014; Lim ve Kye, 2019).

SMART projesi kapsamında okulların, eğitim kaynaklarını öğretmen ve öğrencilerle daha hızlı ve kolay paylaşmalarını sağlamak için bulut depolama sistemleri oluşturulmuştur. Böylece tüm bilgilerin ve verilerin çevrimiçi bir sunucuya taşınması ve herhangi bir zamanda, tüm kullanıcıların içeriğe ulaşması sağlanmıştır. Ayrıca Güney Kore Eğitim Bakanlığı sosyal öğrenmeye önem verdiğinden işbirliğine dayalı öğrenmeyi desteklemiştir. Bu amaçla çevrimiçi kaynaklar yeterli seviyeye getirilerek kullanımı artırılmış böylece öğrencilerin, öğretmenler ve diğer öğrencilerle bu kanallar sayesinde sağlayacağı işbirliği desteklenmiştir. Bu nedenle çevrimiçi kaynaklar, öğrencilerin yalnızca bilgi alışverişinde bulunması, soru sorması ve cevaplaması için kullanılmamakta, onların sosyal becerilerine ve kişisel gelişimine de katkı sağlayacak bir araç olarak görülmektedir (Lim ve Kye, 2019).

2007 yılından bu yana, Güney Kore ders kitaplarının tümünü dijital kitap haline getirmek için çalışmaktadır. Dijital ders kitaplarıyla içeriklerin kolayca güncellenmesi mümkün olmuş ve bu kitaplarla farklı multimedya içerikleri kullanılabilmiştir. Bu kitapların yanı sıra özellikle küçük yaştaki öğrenciler için dijital oyunlar ve etkileşimli içerikler sağlanmıştır (Jang, 2014). 2000’li yılların başında başlayan BİT entegrasyonu için 2008 yılına kadar büyük yatırımlar yapılmış ve sistem büyük ölçüde yapılandırılmıştır. Sonraki süreçte sistemin güçlendirilmesi için çalışmalar devam etmiştir (Kim, Cho ve Lee, 2016).

\section{Hong Kong (Çin)}

Hong Kong'da, okulların BİT entegrasyonu, 1998'den itibaren üç aşamalı gerçekleştirilen "Bilgi Teknolojileri Eğitim Stratejisi” projesi ile başlamıştır. Bu projeler ile öğretmenlerin mesleki gelişimine ve e-öğrenme ortamlarının oluşturulmasına yönelik çalışmalar gerçekleştirilmiştir (Education and Manpower Bureau, 1998). İlk aşamada (1998-2003), okullarda BİT altyapısının oluşturulması, BİT kullanımının sınıflara entegre edilmesi ve e-öğrenme ortamlarının oluşturulmasına yönelik çalışmalar yürütülmüştür. İkinci aşamada (2004-2007) hem teknik hem de pedagojik alandaki çalışmalara, üçüncü aşamada ise (2008'den günümüze kadar) öğrenci merkezli e-öğrenme ortamlarının oluşturulmasına yönelik çalışmalara odaklanılmıştır (Kong, Chan, Huang ve Cheah, 2014). Bu çalışmalar kapsamında birçok okul; eğitimde BİT entegrasyonunu, tebeşir ve yazı tahtasının yerine multimedya sunumlarını/animasyonlarını kullanma olarak algılamıştır. Yine de okullar BİT entegrasyonunun müfredatlara uygulanması için güçlü bir liderlik yapmış ve BİT entegrasyon çalışmalarını yürütebilmişlerdir (Wong ve Li, 2006). 
Hong Kong hükümeti e-öğrenme çalışmalarından sonra, farklı alanlarda BíT kullanımının yaygınlaşması için öğretmenler arasında öğrenme topluluklarının oluşturulmasıyla ilgili çalışmalar başlatmıştır. Öğretmenlerin kullandığı materyaller, çevrimiçi ortamlara aktarılmış ve öğretim kaynakları dijital ortamlarda saklanmıştır. Tüm öğretmenlerin bu ortamlardaki dosyaları kullanmalarına, dosyalarla ilgili yorum yapmalarına ve dijital kaynaklarla ilgili bilgileri paylaşmalarına izin verilmiştir (Wong ve Li, 2006).

\section{Singapur}

Singapur hükümeti Asya-Pasifik bölgesinde eğitim teknolojileri politikalarını başarılı şekilde yürüten ülkeler arasında gösterilmektedir. Singapur, Asya'daki ülkelerin geleneksel uygulamalarını çağın gerektirdiği uygulamalarla bütünleştirmek için 90’lı yılların başında BİT çalışmalarına başlamıştır (Luke, Freebody, Shun ve Gopinathan, 2005; Vallance, 2008). Singapur'un BİT entegrasyonuna yönelik politikası; öğrencilerin okuldaki öğrenme süreçlerini geliştiren, bilgi temelli ekonomiye ve dijital vatandaşlığa katkı sağlayan bireyler olarak yetişmesini sağlamaktı. Bu amaçla geliştirilen ve 1997'den 2002'ye kadar uygulanan birinci masterplan (MP1), okulları temel BíT altyapısı ile donatmaya ve öğretmenlerin BİT kullanımını sağlamaya odaklanmıştır (Vallance, 2008). $\mathrm{Bu}$ amaçla Singapur Eğitim Bakanlığı tarafından her öğretmen, BİT'in müfredata entegrasyonu konusunda 30 saatlik mesleki gelişim sürecinden geçirilmiştir. Öğretmenlere kelime işlemci, internet ve diğer BİT araçlarını öğretmek ve eğitim ortamına entegre etmek için eğitimler verilmiştir (Koh ve Lee, 2008). Ayrıca öğretmenlere BİT'e dayalı derslerin tasarımı ve yürütülmesi konusunda yenilikçi yaklaşımlara dayalı eğitimler verilmiş, yaşam boyu öğrenmeyi destekleyici çalışmalar yapılmıştır. Öğretmenlerden okullarda BİT kullanımını ve yaratıcı düşünceyi destekleyecek çalışmalar yapmaları istenmiştir (Kong ve diğerleri, 2014).

2003-2008 yılları arasında uygulanan ikinci masterplan (MP2) ile BİT'in okullarda etkili ve yaygın kullanımına, BİT'in müfredata entegre edilmesine, BİT kullanımı ile sağlanacak öğretim ve değerlendirme ortamlarına odaklanılmıştır. BİT'in müfredata entegrasyonu, Singapur'da eğitimin kilit noktası olmuştur. Bunun için öğrencilerin, toplumun değișen ihtiyaçlarına göre hazırlanmasına odaklanılmıştır. MP1'de öğretmenler BİT'i müfredata dahil etme konusunda farklı yetkinlik seviyelerine sahip olmuştur. MP2'de programların yürütülmesinde öğrencilerin ihtiyaç duyduğu entegrasyon çalışmalarının yapılması konusunda okullara serbestlik tanınmıştır (Koh ve Lee, 2008).

2008 yılında, üçüncü master planı (MP3) başlatılmıştır. MP3, öğrencilerin öğrenme ortamlarını uygun BİT araçlarını kullanarak zenginleştirmek ve öğrencileri gerekli yeterliliklerle donatmak için birinci ve ikinci master planının devamı niteliğindedir (Singapore Educational Technology Division, 2008). 2015'ten itibaren, bilişim alanında öğrenciler yetiştirme vizyonuyla dördüncü master planı (MP4) başlatılmıştır. MP4 ile öğrencilerin 21. yüzyılın yetkinliklerine sahip bir dijital vatandaş olabilmesi için gerekli becerileri kazanmaları hedeflenmiştir. Ayrıca öğrencilerin her zaman, her yerde 
öğrenmesi ve öğrenmenin kişiselleştirilmesi için web ortamındaki çalışmalara odaklanılmıştır (Singapore Educational Technology Division, 2016).

\section{Çin (Shanghai, B-S-J-G, B-S-J-Z)}

1990’lı yılların başında Çin hükümeti eğitim teknolojileri üzerine yapılan çalışmalarını artırarak kaliteli bilgisayar destekli materyallerin ilkokul ve ortaokullarda kullanılması için üniversitelerde bu materyallerin geliştirilmesine yönelik çalışmalar başlatmıştır. 1990 yılından sonra yapılan çalışmalarla BİT, sorgulamaya dayalı öğretimi gerçekleştirmek amacıyla kullanılmıştır. Bu amaçla K12 eğitiminde kullanılmak üzere farklı kategorilerde bilgisayar destekli materyaller hazırlanmıştır. Hem öğretmenlerin sınıfta ders anlatımında hem de öğrencilerin evde kullanabileceği yazılımlar hazırlanmıştır. Bu tür yazılımlar öğrencilerin bir üst seviye okula geçmek için girdiği giriş sınavlarına yönelik bilgileri içermesi nedeniyle öğrencilerin oldukça ilgisini çekmiştir (Zhang, 2002).

Derslerdeki uygulamalarda bilgisayar yazılımları oldukça fazla kullanılmıştır. MS Word programı Çince ve İngilizce gibi derslerde, MS Excel programı matematik gibi hesaplamaların yapıldığı derslerde yaygın olarak kullanılmıştır (Li, 2000). Geometri uygulaması olan SketchPad gibi popüler bilgisayar yazılımları da Çince'ye çevrilerek okullarda kullanılmıştır. Kullanılan yazılımlar hem CD-ROM ortamında hem de web tabanlı öğrenme ortamlarında kullanılacak şekilde hazırlanmıştır.

2000 yllından sonra Pekin, Şangay ve Guangzhou gibi Çin'in büyük şehirlerinde bilgisayar laboratuvarları kurularak donanım ve ağ altyapıları hazırlanmıştır. Ancak Çin'in kırsal kesimlerinde aynı imkanlara ulaşamayan pek çok okul bulunmaktadır (Zhang, 2002). Çin Eğitim Bakanlığı; kırsal kesimdeki okulların da dahil olduğu zorunlu eğitim içinde yer alan tüm ilkokul, ortaokul ve liselerdeki 160 milyon öğrenciye ücretsiz eğitim videosundan oluşan bir içerik havuzu oluşturmuştur (Wu, 2014).

Çin hükümeti, BİT'in sınıf uygulamalarına entegre edilmesi konusunda öğretmen gelişimini ilerletmek için çalışmalar gerçekleştirmiştir. Öğretmen gelişimi için eöğrenme çalışmaları gerçekleştiren hükümet, 2000-2015 yılları arasında 3 aşamalı olarak "Beş Yıllık Okul Eğitim Reformu ve Gelişme Planı"nı geliştirmiştir. Bu planın I. aşamasında, K12 okullarını temel BİT ve internet altyapısı, dijital eğitim kaynakları ile donatmak amaçlanmış; 2000 yılında “Geniş Bant Ağı ile Okulları Birleştirme” çalışması başlatılmıştır (Zhu, Gu, Collis ve Moonen, 2011). Bu plan kapsamında yapılan bir başka çalışma da "K12 okulları için müfredat reformu" ile ilgilidir. Bu iki çalışma, öğretmenlerin BİT'i öğretim uygulamalarına entegre etmelerini ve bu konuda temel becerileri kazanmalarını sağlamıştır. Pekin hükümeti, öğretmenlerin BíT'in öğretmenlik ile bütünleştirilmesi için bazı ön çalışmaların şart olduğunu düşünmüştür. Bu nedenle Milli Eğitim Bakanlığı tarafından öğretmenlerin, BİT'i sınıf içi öğretime entegre etmesi için düzenli olarak teknik ve teorik eğitimler düzenlenmiştir (Kong, Looi, Chan ve Huang, 2017).

2000 yılında başlayan projenin ikinci aşamasında (2006-2010 Beş Yıllık Okul Planı), Çin Milli Eğitim Bakanlığı, öğretmenlerin ve öğrencilerin BİT kullanma yetkinliklerinin 
kapsamlı bir şekilde geliştirilmesi ve sisteme hızlı bir şekilde entegre olmaları için çalışmalar yürütmüştür (Beijing Education Bureau, 2006). Bu ulusal politika, hükümetin e-öğrenme uygulamalarının sınıf öğretiminde etkili bir şekilde kullanılmasına odaklanmıştır. Bu nedenle Pekin hükümeti, e-öğrenme ile öğretmenlerin katılımını artıracak faaliyetler gerçekleştirmiştir. BİT'in sınıf öğretimine etkili bir şekilde entegre edilmesi için öğretmenlere, BİT destekli kaynaklar, örnekler ve yazılımlar sağlanmıştır. Ayrıca e-öğrenme ortamlarında K-12 öğretmenlerinin öğretim tasarımlarını birbirleriyle paylaşmasını ve tartışmasını sağlayacak Ulusal Eğitim Ağı kurulmuştur (Kong ve diğerleri, 2017).

Projenin son aşamasında 2015 yılında hükümet, öğretmenlerin BíT’i kullanma yetkinliklerini geliştirme projesini başlatmıştır (Beijing Education Bureau, 2015). Ayrıca e-öğrenme ortamlarını aktif şekilde kullanmak için bu ortamlara yönelik kaynakların geliştirilmesi ve çevrimiçi kaynakların öğretmenlere ulaştırılması için bazı şirketlerle işbirliği yapılmıştır. Bu kapsamda dijital öğretim ortamlarına yönelik çalışmalar başlatılmıştır. Oluşturulan dijital kampüsler ile bilimsel ve etkili e-öğrenmeyi destekleyen, öğretim, araştırma ve okul-aile bağlantısını sağlama gibi farklı açılardan katkı sağlayacak e-öğrenme ortamları hazırlanmıştır (Huang, 2009).

\section{Tayvan}

1986 yılında okullarda BİT teknolojilerinin derslerde kullanılması ile ilgili Tayvan Milli Eğitim Bakanlığı, altı yıllık resmi bir plan açıklamıştır. Bu planın amacı Bilgisayar Destekli Eğitimin (BDE) uygulanması, öğretmen eğitimi ve BDE'nin okullarda kullanılmasını teşvik etmekti (Alessi ve Shih, 1989; Mau, 1988). Bu proje ile aynı zamanda her ortaokul ve lisede bilgisayar sınıflarının oluşturulması amaçlanmıștır. 1987 yılında, devlet fonları, lise ve ortaokullara belirli miktarda donanım sağlamıştır. 1988 yılında öğretmenler BDE konusunda eğitilmiş ve BDE'ye yönelik eğitim yazılımları devlet finansmanı ile geliştirilmiştir (Alessi ve Shih, 1989).

Geliştirilen BDE yazılımlarının okullara dağıtımı yapılmış ve öğretmen eğitimleri tamamlanmış olmasına rağmen birkaç yıl içinde bilgisayar donanımlarının çoğunun kullanılmadığı ve bilgisayar yazılımlarının sınıf derslerine entegre edilemediği görülmüştür. Bilgisayarları standart müfredata dahil edecek konular da okullarda uygulanamamıştır. Birçok okulda bilgisayar sınıfları öğretimsel amaçlardan daha çok idari amaçlar için kullanmıştır (Usa ve Twu, 2002). Bu problemlerin ortaya çıkışındaki sebepler; BDE'ye uygun olmayan müfredatlar, yetersiz öğretmen eğitimi, donanımların kullanımı konusunda yetkililerin yetersiz kalması (Hsin, 1994), yürütülen çalışmanın büyüklügü nedeniyle hükümetin uygulamayı yeterince takip etmesinin zor olması gibi sıkıntılar gelmektedir. Bir süre sonra yerel okullar, ana proje kapsamından çıkarak bilgisayarları öğretime entegre etmek için kendi stratejilerini ve planlarını geliştirip kullanmaya başlamışlardır (Usa ve Twu, 2002).

1990'ların sonunda, bakanlık önceki uygulamadan alınan sonuçlara dayanarak eğitim teknolojisindeki reform çalışmalarını değerlendirmiş ve 1997'de teknolojinin öğretime entegrasyonunu güçlendirecek 3 yıllık teknoloji reform planını yayınlamıştır (MOE ROC- 
Taiwan, 1996). Bu planın 3 temel bileșeni bulunmaktadır: Temel Bilişim Eğitimi Planı, Ulusal Bilişim Altyapısı Projesi ve Orta Ölçekli Uzaktan Eğitim Planı. Bu 3 proje çerçevesinde yapılan çalışmalar şu şekildedir:

- Tüm okul seviyelerinde bilgisayar donanımı, yazılımı ve ăg alt yapısını oluşturmak,

- BDE ve bilgisayar ağlarının kullanımıyla, öğretim kalitesini artırmak

- Eğitim teknolojileriyle ilgili dijital kaynakları geliştirmek ve bunu öğretmen, öğrenci ve vatandaşlara sunmak,

- Yaşam boyu öğrenmenin amaçlarına ulaşmak için uzaktan öğrenme teknolojisini kullanmak,

- Uzun vadeli ve sistematik eğitim teknolojisi görevlerini gerçekleştirecek iyi planlama, organizasyon ve tesisleri oluşturmak.

Tayvan Milli Eğitim Bakanlığı, üç yıllık program sonrasında uygulanacak ikinci bir uygulama programı hazırlamıştır. Bu planda önceki plana göre yapılan en temel farklılık ağ ortamlarının oluşturulması olmuştur. Bu plan çerçevesinde yapılan çalışmalar şöyledir (MOE ROC-Taiwan, 1998):

- İlkokul düzeyinde başlatılacak BİT müfredatı oluşturmak,

- BİT ihtiyaçlarını karşılamak için profesyonel bilgisayar becerilerine yönelik eğitimler sağlamak,

- Öğretim stratejilerini kullanarak BİT'i tüm alanlara entegre etmek,

- Uzaktan öğrenmeye yardımcı olacak ağ yapılarını oluşturmak,

- Bilgi paylaşımı için çevrimiçi ortamları oluşturmak.

Önceki planlara göre bu beş hedef ile daha özel görevlerin gerçekleştirilmek istendiği görülmektedir. Ancak bu amaçlarla örtüşen bir öğretim tasarım planının hazırlanmaması bir eksiklik olarak belirtilmiştir. Bu nedenle bakanlığın teknolojik gelişmelere fazla ilgi gösterdiği ancak öğrencilerin bireysel farklılıklarını ve öğrenme stratejilerini gözden kaçırdığı belirtilmiştir (Usa ve Twu, 2002).

Uzaktan eğitim çalışmaları Tayvan'da eğitim teknolojilerine yönelik yapılan çalışmalar içerisinde ön planda olmuştur. Tayvan hükümeti 1980'lerden sonra e-öğrenme üzerine araştırma ve geliştirmeye önemli yatırımlar yapmıştır. 1997 yllında okullarda BİT altyapısının oluşturulması ile ilgili 10 yıllık bir program oluşturulmuş ve Tayvan eğitiminde e-öğrenme çalışmaları resmen başlamıştır. Bu kapsamda K12 eğitimine yönelik olarak içerik geliştirilmesine ve donanım alt yapılarının oluşturulmasına önem vermişlerdir. Birinci ve ikinci aşamada elde edilen başarılara dayanarak, üçüncü aşamaya (2009-2014) devam edilmiş ve şu hususlara odaklanılmıştır (Kong ve diğerleri, 2014):

- 21. yüzyıl becerilerinin gelişimine odaklanmak

- Dijital okuryazarlığı müfredat içerisine yerleştirmek 
- Mobil öğrenme programını başlatmak

1997'den 2002'ye kadar, Tayvan hükümeti öğretmenlerin BIT araçlarını sınıf ortamında kullanması için donanım altyapısına odaklanmıştır. 2013'te başlayan "Yarının Okunması" programı ile Milli Eğitim Bakanlığı, üniversitelerden danışman akademisyenler atayarak okullarda mesleki gelişim çalışmaları, atölyeler, konferanslar, öğretmenler ve müdürler için çevrimiçi kurs gibi çeşitli çalışmalar düzenlemiştir. Bu çalışmalar kapsamında okulların BİT altyapısının yenilenmesine, e-öğrenme ortamları ve öğrencilerin 21. yüzyll becerilerini geliştirecek şekilde öğretmen gelişimine önem verilmiştir (Kong ve diğerleri, 2014).

\section{Türkiye'de K12 Düzeyindeki Okullarda Yapılan BİT Entegrasyon Çalışmaları}

Türkiye'de BİT’in eğitimde kullanılması ile ilgili çalışmalar, bilgisayarın eğitimde kullanılmaya başlandığı 1984 yılından sonra artmıştır (Uşun, 2004). 1985 yılında, bilgisayar destekli eğitimin (BDE) başlatılması kapsamında okullara bilgisayar laboratuvarları kurulmaya başlanmış (MEB, 2003), aynı tarihlerde öğretmenlerin Bilgisayar Destekli Eğitime (BDE) başlayabilmesi için hizmetiçi eğitimler verilmiştir. 1989'da Altıncı Beş Yıllık Kalkınma Planı ve 1996'da Yedinci Beş Yıllık Kalkınma Planı kapsamında teknolojik gelişmelerin eğitim müfredatlarına yansıtılması gündeme gelmiştir (Starateji ve Bütçe Başkanlı̆̆l, 2019).

Türkiye'deki BİT gelişmeleri BDE’ye paralel bir şekilde devam etmiştir. 80’li yılların sonunda Türkiye Bilimsel ve Teknik Araştırma Kurumu (TÜBİTAK), BİT altyapısı ve yazılımlarının okullara sağlanması konusunda çalışmalar başlatmış, bu çalışmalara özel sektörden ve üniversitelerden de destek sağlanmıştır (Keser, 2011). Bu kapsamda yapılan projeler ile öğrencilerin BİT teknolojilerini kullanma konusunda ilgilerinin arttığı ancak öğretmenlerin bu teknolojilerin kullanımı konusunda yeteri kadar bilgi sahibi olmadığı ve okullara gönderilen yazılımların müfredatlar ile uyumlu olmadığı belirtilmiştir (Küpçüoğlu, 2008). MEB tarafından, Dünya Bankası desteği ile Endüstriyel Okullar Projesi (1985-1994), Yaygın Mesleki Eğitim Projesi (1987-1995) ve Milli Eğitim Geliştirme Projesi (1990-1999) yürütülerek okullardaki bilgisayar laboratuvarlarının kurulumu ve alt yapı çalışmalarına hız verilmiştir. Bu projelerde öğretmenlere bilgisayar okuryazarlığı eğitimleri verilmiştir (Fiş Erümit, Gedik, ve Göktaş, 2016). Dünya bankası raporlarında bu projelerin başarıya ulaştığı yazılsa da uygulamada istenilen başarıya ulaşılamamıştır. Donanım alt yapısı sağlanmış ancak donanımların kullanımı istenilen seviyeye gelememiştir. Öğretmenlerin çoğu, donanımları kullanacak bilgi ve beceriye sahip olamamıştır. Çünkü öğretmen ve yöneticilere BİT entegrasyonu konusunda yeterli hizmetiçi eğitim verilememiş, müfredatlar BİT entegrasyonuna göre düzenlenememiştir (Akbaba Altun, 2006).

1995 yılında MEB ve TÜBİTAK işbirliğinde hazırlanan öğretim yazılımları, altyapısı tamamlanan okullara gönderilmiştir (Akkoyunlu ve İmer, 2012). 1998 yılında başlayan Temel Eğitim projesinin 1. fazında BİT araçlarının 8 yıllık zorunlu eğitimin tüm kademelerinde kullanılması ile öğrencilerin aktif öğrenenler olarak bilgiye ulaşma ve problem çözme becerilerini kazanması amaçlanmıştır (Starateji ve Bütçe Başkanlığl, 
2019). Bu yıllarda donanım ve yazılım yatırımları artarak BİT entegrasyon çalışmaları hızlanmıştır. Temel Eğitim projesinin 2. fazında BİT sınıflarının kurulması ve yazılımların satın alınması devam etmiştir. İlköğretimde görev yapacak, donanım ve yazılımlarla ilgilenecek formatör öğretmenlere BİT entegrasyonu konusunda hizmetiçi eğitimler düzenlenmiştir (MEB, 2005).

BİT'in eğitimde kullanılmasını yaygınlaştırmak amacıyla 1998'de MEB ve Dünya Bankası Ekonomik Geliştirme Kurumu, 15 ülkenin yer aldığı World Link Projesini uygulamaya koymuştur (Gürcan, 2008). Türkiye'de 15 ildeki 22 lisede uygulanan bu projenin amacl, çeşitli ülkelerdeki öğretmen ve öğrencilerin internet üzerinden ulaşacağı bir platform oluşturmaktı. Proje kapsamında öğrencilerin interneti kullanarak bilgilerini paylaşması ve okullarla ortak projeler hazırlanması sağlanmıştır (Erçil Çağıltay, 2000).

MEB 1999 yılında eğitimin kalitesini artırmayı amaçlayan Müfredat Laboratuvar Okulları Modeli (MLO)'ni uygulamaya koymuştur. Proje kapsamında 23 ildeki ilköğretim ve ortaöğretim okullarına eğitim materyali sağlanmıştır. Ayrıca okullara bilgisayar, yazıcı, faks makinesi, tepegöz, tarayıcı ve TV gibi çeşitli donanımlar da sağlanmıştır. MLO okulları bulundukları bölgede prototip olarak diğer okullar için örnek olmuştur (Kılış, 1998). Bu proje ile okullardaki bilgisayar ve bilgisayar laboratuvarı sayısında artış olmuş, internet bağlantıları artış (\%17) göstermiştir (MEB, 2002).

2003 yılında MEB’e bağlı tüm okullarda e-öğrenmeyi teşvik etmek için internet erişimi sağlama çalışmaları başlatılmıştır. 2006 yılında tüm okulların internete erişimi sağlanmıştır (Eryılmaz \& Salman, 2014). 2005 yılında zorunlu eğitimdeki öğrencilere ücretsiz ders kitapları dağıtılarak her öğrenciye ortak bir içerikle eğitim verilmeye başlanmıştır (Bayrakçı, 2005). 2006 yılında MEB yabancı dil öğretimini desteklemek amacıyla interaktif dil öğretimi yapılması için öğrenciler için ücretsiz yazılımlar (DynEd) kullanılmasını sağlamıştır (Yiğit, 2013).

2011 yılında BíT'in okullarda yaygınlaştırılması amacıyla Fırsatları Artırma ve Teknolojiyi İyileştirme Hareketi (FATİH) projesi uygulanmaya başlanmıştır. Proje ile eğitim-öğretimde fırsat eşitliği yaratmak ve BİT araçlarının ilkokul, ortaokul ve liselerde daha etkin kullanılmasını sağlamak amaçlanmıştır (MEB, 2012). Bu kapsamda; donanım ve yazılım alt yapısının sağlanması, eğitsel e-içeriklerin oluşturulması, öğretmenlerin hizmetiçi eğitimi, BİT kullanımının sağlanması ve BİT entegrasyonu yapılan öğretim programlarının etkin kullanımı hedeflenmiştir (MEB, 2020a). Proje ile her öğrenciye tablet verilmesi, okulların internet altyapılarının yenilenmesi, sınıflarda etkileşimli tahtaların kullanılması da planlanmış ve BİT teknolojilerine her sınıfın ulaşması sağlanmıştır (MEB, 2012b). Bu kapsamda e-içerik uygulamalarının kullanımı için 2012 yılında Eğitim Bilişim Ağı (EBA) internette yayınlanmıştır. EBA, BİT araçları kullanılarak her sınıf seviyesinde oluşturulmuş e-içeriklerin bulunduğu bir platformdur. Bu sayede öğretmenlerin ders anlatımlarında yararlanabileceği, öğrencilerin bireysel olarak da kullanabileceği etkileşimli ve eğitici içeriklere ulaşmaları sağlanmıştır (Fiş Erümit, Gedik ve Göktaş, 2016). EBA yenilenen içerikleri ve uygulamaları ile güncel tutulmaya devam edilmektedir (MEB, 2012). 


\section{TARTIŞMA VE SONUÇ}

Bu çalışmada, PISA sınavlarında ilk 10 içerisine giren Asya-Pasifik bölgesindeki ülkelerin BİT'i eğitim süreçlerine nasıl entegre ettikleri ve BİT'e yönelik politikaları ile ilgili yapılan çalışmalar incelenmiştir. Bu bölümde ülkelerin yaptıkları BİT entegrasyon çalışmaları özetlenerek, bu çalışmaların Türkiye'de yapılan BİT entegrasyon çalışmalarıyla karşılaştırması yapılmıştır. PISA'nın pek çok ülkede kapsamlı ve düzenli bir şekilde gerçekleştirilmesi nedeniyle, elde edilen sonuçlar ülkelerin eğitim politikalarının karşılaştırılması ve çağın gerektirdiği düzenlemelerin yapılması açısından oldukça önemlidir (OECD, 2009). Bu nedenle çalışmanın, incelenen ülkelerin BİT entegrasyonuna yönelik politikalarını karşılaştırmak açısından önemli olduğu düşünülmektedir. Ekonominin küreselleşmesi ve teknolojide yaşanan gelişmelerle birlikte bilgi ve iletişim teknolojilerinde hızlı bir değişim ve gelişim yaşanmış, eğitim ortamlarının da bu değişim hızına ayak uydurması gerekmiştir. BİT'in bu derece hızlı bir değişim göstermesi, eğitim reformlarını da etkileyerek eğitimin yeniden şekillenmesini sağlamıştır. Birçok ülkenin, son yıllarda eğitimde kazandığı ivmenin BíT alanında yapılan reformlar ve planlamalarla sağlandığı belirtilmiştir (Wong \& Li, 2006). Eğitim sürecinin bir bütün olduğu düşünüldüğünde PISA'da alınan başarının eğitim sistemindeki başarılı reformların bir göstergesi olduğu, bunun da BİT entegrasyonuyla doğrudan ilişkili olduğu görülmektedir.

ABD ve Avrupa Birliğine üye ülkeler 2000'li yıllardan sonra ekonomide düşüş gösterirken, başta Çin olmak üzere Asya-Pasifik bölgesindeki ülkelerin ekonomisi yükselişe geçmiştir (Özekicioğlu ve Kılıç, 2017). Yaşanan bu yükselişe paralel olarak uluslararası yapılan PISA değerlendirmesi gibi ölçümlerde de bu ülkelerin üst sıralarda yer aldığı görülmüştür. Küresel boyutta yaşanan bu değişim şüphesiz ülkelerin kalkınma planları ve eğitim reformları ile ilgili olmuştur. Nitekim incelenen ülkelerde, özellikle 2000 yılından sonra eğitimde BíT entegrasyonuna çok önem verildiği, bu konuda büyük harcamalar yapılarak okulların gerekli altyapı, donanım, araç-gereç ve eğitim materyali ile donatıldığı görülmektedir. Bu nedenle Asya-Pasifik bölgesindeki ülkelerin BİT entegrasyon çalışmalarının, bu değişim sürecini anlamaya katkı sağlayacağı açıcça görülmektedir.

Türkiye'de birçok BİT entegrasyon çalışması yapılmasına rağmen, PISA'daki sıralaması Türkiye'nin sıralamasından yüksek olan Asya-Pasifik bölgesi ülkelerinin BİT entegrasyon çalışmalarından farklı dersler çıkarılabileceği görülmektedir. Teknolojinin eğitim ortamlarına entegre edilmesine yönelik yapılan çalışmalar incelendiğinde; BİT'in sadece teknolojik çalışmalarla etkin şekilde kullanılamayacağı, bunun yerine sürecin daha kapsamlı düşünülmesi gerektiği anlaşılmaktadır (Çelen, Çelik ve Seferoğlu, 2011; Yurttaş Kumlu, 2018). Çin ve Singapur'da 90’lı yıllarda, Japonya, Güney Kore, Hong Kong ve Tayvan'da ise 2000'li yılların başında, kapsamlı BİT entegrasyon çalışmalarına başlandığı görülmektedir. Türkiye'de ise 90 'lı yıllarda entegrasyon çalışmalarının arttığı görülmektedir. 0 yıllarda İngiltere, Fransa, İtalya ve Belçika'daki okulların \%85'inde internet bağlantısı yapılmıştır. Bu durum BİT entegrasyonu konusunda ülkemizin o 
dönemlerde Avrupa ülkelerinin gerisinde olduğunu göstermektedir (Yıldız, 2008; Topu, 2010). Asya-Pasifik bölgesi ülkeleriyle karşılaştırıldığında ise Türkiye'nin Çin ve Singapur ile aynı yıllarda, Japonya, Güney Kore, Hong Kong ve Tayvan'dan daha önce BİT entegrasyon çalışmalarına hız verdiği görülmektedir. Nüfus yoğunluğuna bakıldığında Türkiye; Tayvan, Güney Kore ve Hong Kong'dan daha fazla nüfusa sahip olsa da Japonya ve Çin'in gerisindedir. Özellikle Çin ve Japonya gibi nüfus ve öğrenci yoğunluğu Türkiye'dekinden fazla olan ülkelerde PISA başarısının yüksek olması dikkat çekicidir. Her ne kadar öğrenci başına yapılan eğitim harcaması eğitimin kalitesinin artırılmasında bir etken olarak görülse de yapılan harcamaların öğrenci başarısını açıklamadaki payı ancak \%9 olarak belirtilmiştir (Kılıçaslan ve Yavuz, 2019). Ayrıca Çin'in PISA'ya katılmak için belirli eyaletlerinden öğrenci seçimi yaptığı, kırsal kesimlerden öğrenci seçildiğinde başarısının düşebileceği belirtilmektedir (OECD, 2018). Türkiye'nin, BİT entegrasyonu konusunda Asya-Pasifik ülkeleriyle benzer çalışmalar yaptığı görülmektedir. Özellikle Türkiye'de FATİH projesi ile BİT entegrasyon çalışmaları ivme kazanmıştır. Ancak okullarda sadece BİT’e yönelik çalışmalar yapılması öğrenci başarısını doğrudan etkilememektedir. Etkili BİT kullanımı için büyük bir okul değişim süreci gerekmektedir (Honey, Culp ve Carrigg, 2000). BİT'in daha çok, okul sisteminde ve kültüründe yapılacak reformların bir parçası olarak görülmesi gerektiği belirtilmektedir (Bober, 2002). Örneğin Güney Kore ve Çin'de Konfüçyüs felsefesinin etkili olduğu ve bu etkinin okul kültürüne de yansıyarak başarının artmasına katkı sağladığı belirtilmektedir. Bu toplumlarda eğitim ve eğitim almış kişiler topluma fayda sağlayan önemli unsurlar olarak görülmektedir. Bu nedenle aileler çocukların uzun saatler disiplinli bir şekilde eğitim görmesine büyük katkı sağlamaktadır (Bakioğlu ve Baltacı, 2019).

Güney Kore'deki, SMART projesi kapsamında yaygınlaştırılan dijital kaynakların öğrencilerin yaratıcılıklarını, bilgi okuryazarlığı ve problem çözme becerilerinin geliştirilmesinde faydalı olduğu belirtilmiştir. Ayrıca öğretmenler bu proje ile öğrencilerin birçok dersteki başarısının olumlu etkilendiğini, iletişim ve öğrenme becerilerinin geliştiğini belirtmiştir (Lim ve Kye, 2019). Ancak öğretmenler BİT çalışmalarına yönelik tam bir değişimin yakalanması için eğitime sürekli finans desteği sağlanması, BİT ile ilgili personel gelişiminin desteklenmesi, kaynakların uygun şekilde tahsis edilmesi ve yazılımların sağlanmasının gerekli olduğunu belirtmiştir (Wong ve Li, 2006). SMART projesi, küresel eğitim sıralamasında 29. sırada yer alan Güney Kore'nin mevcut eğitim sisteminin gelişmesini sağlamıștır. Bu proje Güney Kore'de BİT çalışmalarını desteklemiş ve bunların tüm öğrencilere ulaşmasını sağlayarak eğitimdeki eşitsizliği gidermiştir. SMART projesi ile BİT'in öğrencilerin gelişimine katkı yaptığı belirtilmiştir (Jang, 2014). Bu nedenle öğrencileri geleceğe hazırlamak için BİT imkanlarını fırsata çevirecek şekilde kullanmak gerektiği görülmektedir. Türkiye, OECD ülkeleri arasında sosyo-ekonomik dengesizliğin öğrencileri en çok etkilediği ülkeler arasındadır (Bozkurt, 2014). Bu nedenle eğitimde hem kaliteyi hem de fırsat eşitliğini sağlayacak BİT entegrasyon çalışmalarının önemi açıkça ortaya çıkmaktadır. FATİH projesi ile donanım, altyapı ve dijital içerik sunma çalışmaları ön plana çıksa da yapılan tüm çalışmaların bakanlık, öğretmen, öğrenci ve veli açısından daha koordineli 
yürütülmesi gerektiği görülmektedir. Böylece sosyo-ekonomik dengesizlik nedeniyle eşit imkanlara sahip olamayan öğrencilere bakanlığın gerekli imkanları sağlaması ve öğrencilerin eğitim açısından eşit koşullara erişmesi mümkün olabilir.

PISA, TIMMS, PIRLS gibi uluslararası ölçümlerdeki sıralamanın, sadece ülkelerin eğitim yatırımları ve BİT entegrasyonu politikalarına değil; eğitim sürecine katılan tüm paydaşlarının niteliği ile açıklanması mümkündür. Özkan, Özkan ve Güvendir (2019) Singapur ve Türkiye'deki okullarda öğretmenlerin mesleki gelişimlerini karşılaştırdığı çalışmada, Singapur'da mesleki eğitime katılan öğretmenlerin oranı Türkiye'de mesleki eğitime katılan öğretmenlerden oldukça fazla olduğu belirtilmiştir. Öğretmenlerin okuldaki değişim sürecinde büyük bir etkisi olduğu göz önüne alındığında, öğretmen kalitesinin eğitimdeki başarıyı açıklayan en önemli faktörlerden birisi olduğu belirtilmiştir (Tygret, 2017; Vogt ve Rogalla, 2009). Ayrıca 2009 yılından beri PISA'da ilk 10 içerisinde yer alan ve 2015 yılında 1. olan Singapur, OECD raporunda bu başarısındaki en etkili faktörün öğretmenlerinin kalitesi olduğunu belirtmiştir (OECD, 2018). Singapur eğitim sistemi dünyadaki en iyi eğitim sistemleri arasında gösterilmektedir. Singapur'da öğretmenlere mesleki gelişimleri için sürekli destek verilmekte ve fırsatlar sunulmaktadır. Yardımcıŏlu ve Gürdal (2012) eğitimden istenilen başarının elde edilmesinde eğitim sürecinin niteliği ve kurumsallaşmanın önemli olduğunu vurgulamıştır. PISA sınavlarında üst sıralarda yer alan Singapur, Güney Kore ve Japonya gibi ülkelerin başarısının eğitim sisteminin her alanının planlanması ve bu planların titizlikle uygulanması ile ilgili olduğu belirtilmiştir. Hatta bu ülkelerde seçmeli dersler bile öğrencinin başarısını artıracak unsurlar olarak düşünülmekte ve bu derslerle ilgili planlamalar ayrıntılı olarak yapılmaktadır (Çiftçi ve Özok, 2013). BİT'in sınıf ortamına ve eğitime uyarlanması başarının odak noktası olarak görülmemelidir. BİT entegrasyon çalışmaları; öğretmen eğitimi, okul kültürü, temel bilimlerin BİT çalışmalarıyla desteklenmesi, seçmeli ve zorunlu derslerin verimli uygulanması gibi eğitim ortamına bütüncül yaklaşımlar ile istenilen başarıyı sağlayacaktır. Nitekim teknolojiyi üreten başlıca ülkelerden olan Japonya'nın BİT entegrasyon çalışmalarına diğer ülkelere göre daha geç başlamasına rağmen PISA'da gösterdiği başarı eğitim ortamına bütüncül yaklaşımın en iyi örneğidir. Ancak PISA özelinde baktığımızda özellikle son yıllarda Çin'in çok geniş bir coğrafyada bulunması ve sadece belirli eyaletlerle sınavlara katılarak başarı göstermesi düşündürücüdür. Çin'in tüm eyaletlerinden seçilecek öğrencilerle PISA'ya katılmasının PISA başarısını düşüreceği düşünülmektedir (Tanrısevdi ve Kıral, 2018). Ancak Japonya, Singapur ve Çin adı altında PISA'ya katılan Shanghai ve Hong Kong gibi bölgelerin eğitim sürecine sadece bir gereklilik değil, aynı zamanda toplumdaki her türlü değişimin başlangıcı olarak bakıldığı düşünüldüğünde, her türlü eğitsel politikanın ancak toplumların bu yeniliklere bakış açısıyla işe yarayacağı görülmektedir. Bu nedenle BİT entegrasyon çalışmaları da dahil, yapılan her türlü değiş̧ikliğin kültürler için uyumlu olması ya da öncelikle eğitim kültürünün tümden değiştirilmesi gerekmektedir.

Türkiye'de BİT entegrasyonuyla ilgili özellikle 90'lı yıllardan itibaren büyük yatırımlar yapılmış ancak bu teknolojilerin eğitim ortamına entegre edilmesi ve etkin şekilde 
kullanılmasıyla ilgili sorunlar yaşanmıştır. Özellikle okullara sağlanan araç-gereç ve teknolojilerin amacina uygun ve verimli şekilde kullanılmasıyla ilgili sorunlar aşılamamıştır (Akbaba Altun, 2006; Çakır ve Yıldırım, 2009; Akıncı, Kurtoğlu ve Seferoğlu, 2012; Şendurur ve Arslan, 2017). Bu sorunların temel nedenleri; yeterli eğitim yazılımının olmaması, öğretmen ve yöneticiler için BíT entegrasyonuna yönelik hizmetiçi eğitimlerin yeterli olmaması, öğretmenlerin hazır içerik beklentisi, öğretmenlerin yaşadığı teknoloji-yöntem karmaşası, müfredatların BíT entegrasyonuna uygun hazırlanmaması, MEB'in önceki projelerle ilgili yeterli değerlendirme yapmadan yeni projelere geçmesi olarak görülmektedir (Fiş Erümit, Gedik ve Göktaş, 2016; Özdemir, 2010; Şendurur ve Arslan, 2017). Ayrıca öğretmenlerin Bi̇T entegrasyonu konusunda görevlerini tam anlamıla gerçekleştirmesinin bu süreçte önemi vurgulanarak Türkiye'deki öğretmenlerin bunu gerçekleștirebilme konusunda eksik kaldıkları belirtilmektedir (Göktaş, Yıldırım ve Yıldırım, 2008; Usluel, Kuşkaya Mumcu ve Demiraslan, 2007; Doğan, Çınar ve Seferoğlu, 2016; Özkan, Özer Özkan ve Acar Güvendir, 2019). Ancak her ne kadar uygulamada yaşanan sorunlar olsa da Türkiye'de eğitim teknolojilerine yapılan yatırımların sonucunu günümüzde görebildiğimizi söylemek mümkündür. Nitekim 2020 yllında küresel boyutta yaşanan Covid-19 salgınında, Türkiye'nin örgün eğitimlere ara vererek 1 hafta gibi kısa bir sürede uzaktan eğitim sürecine başlaması bunun en iyi örneğidir. MEB, uzun yıllardır alt yapısını oluşturarak zenginleştirdiği içerik portalı EBA ve bu süreç için hızlıca yayın hayatına geçirdiği 3 tane EBA TV kanalı ile uzaktan eğitim sürecini yürütmüştür. Türkiye hem internet üzerinden senkron ve asenkron eğitimler hem de EBA TV üzerinden eğitimler yürüterek Dünya'da ulusal çapta uzaktan eğitim yürüten iki ülkeden birisi olmuştur. PISA'da üst sıralarda yer alan Çin de bu salgın sürecinde, öğrencilerin internetten eğitim almasını sağlayan ülkelerden birisi olmuştur (MEB, 2020b). Çin'in eğitim teknolojilerine yönelik yaptığı reformlar ve e-öğrenmeye yönelik yatırımları bu sürece geçişi kolaylaştırmıştır. Türkiye'de altyapı, içerik ve uygulamaları hızlı bir şekilde uzaktan eğitim sürecine entegre eden Milli Eğitim Bakanlığı'nın bunu gerçekleştirmesindeki en büyük etkenin, şüphesiz yıllardır eğitim teknolojilerine yapılan yatırımlar olduğu görülmektedir. Yapılan araştırma sonucunda eğitimde BíT entegrasyonuyla ilgili ülkelerin ön planda tuttukları çalışmalar Şekil 2'de verilmiştir. 


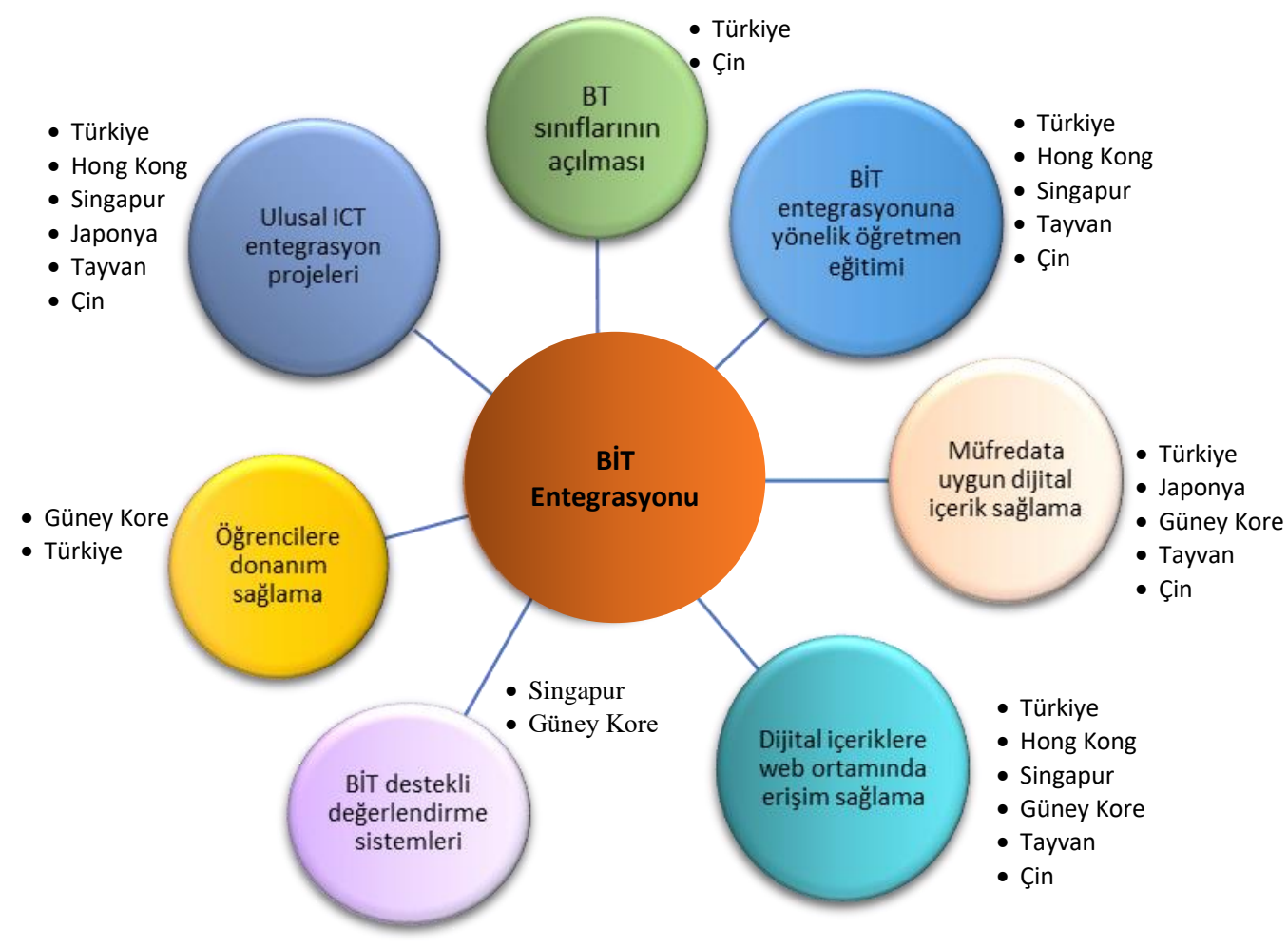

Şekil 2. Ülkelerin Eğitimde Bi̇T Entegrasyonuyla İlgili Gerçekleştirdiği Çalışmalar

Şekil 2'ye göre ülkelerin BİT entegrasyonu kapsamında en çok ulusal çapta projeler gerçekleștirdikleri ve dijital içeriklere erişim sağlama çalışmaları yaptıkları görülmektedir. Ulusal çaplı projeler en çok donanım alt yapısı ve internetin sağlanması çalışmalarını kapsamaktadır. Ülkelerin BíT entegrasyon çalışmaları kapsamında ön planda tuttukları diğer çalışmalar sırasıyla, müfredata uygun dijital içerik sağlanması, BİT entegrasyonuna yönelik öğretmen eğitimi, BİT destekli değerlendirme sistemleri, BT sınıflarının açılması ve öğrencilere tablet, telefon gibi donanım sağlama şeklinde olmuştur.

\section{5. ÖNERILER}

Elde edilen sonuçlar ışığında Türkiye'de eğitimde BíT entegrasyon çalışmalarının gerçekleştirilmesine yönelik öneriler şöyledir:

- Türkiye'de pek çok BíT entegrasyon projesi gerçekleştirilmiştir. Ancak kimi zaman projelerde yapılan çalışmaların pratiğe geçirilmesinde, öğretmen, öğrenci ve okul kültürünün adaptasyonunda sıkıntılar yaşanmıștır. Bu nedenle bakanlık bünyesinde, entegrasyon çalışmalarını okul, öğretmen ve öğrenci açısından değerlendirecek proje takip ve koordinasyon birimlerinin oluşturulması 
gerekmektedir. Bu birimlerin süreç içerisinde değerlendirmelerini yaparak hızlı bir şekilde revizyonları gerçekleştirmesi gerekmektedir.

- Entegrasyon çalışmalarının gerçekleştirilmesinde en temel bileşen öğretmenlerdir. $\mathrm{Bu}$ nedenle öğretmenlerin mesleki gelişim ve teknoloji entegrasyon çalışmaları konusunda kapsamlı eğitimlere tabi tutulması, bu amaçla yapacakları çalışmaların Milli Eğitim Bakanlığı tarafından desteklenmesi gerekmektedir. Ayrıca her yıl öğretmenlerin kendi branşında ve teknoloji entegrasyonu konusunda bireysel çalışma yapması zorunlu tutulabilir, her 5 yılda bir kapsamlı bir proje çalışması (Arge projeleri, Tübitak, Avrupa Birliği Projeleri vb.) içerisinde bulunması teşvik edilmelidir. Bu kapsamda yapılacak çalışmaların bir değerlendirme sistemi ile takip edilmesi ve başarılı bulunmayanların çalışmalarını geliştirmelerine, başarılı bulunanların ise ödüllendirilmesine yönelik çalışmalar yapılabilir.

- Dijital çağda öğretmen ve öğrencilere zengin öğretim materyali desteği sunulması gerekmektedir. Bu amaçla EBA bünyesinde yer alan içeriklerin zenginleştirilmesi, içerik bulunmayan ya da az sayıda içerik bulunan derslere ait nitelikli içeriklerin eklenmesi gerekmektedir.

Ülkelerin teknoloji entegrasyon çalışmaları ve PISA değerlendirmelerine yönelik öneriler ise şöyledir:

- PISA kapsamında öğrencilere, velilere ve okul yönetimine uygulanan anketlerin sonuçlarına dayalı olarak öğrencilerin başarısının ve başarısızlığının sebeplerini irdeleyen, öğrencilerin okul dışında teknolojiye erişimlerini araştıran, ülkeler bazında karşılaștırmalı çalışmalar yapılabilir.

- Covid-19 pandemisinde dünya genelinde örgün eğitime yönelik uzaktan eğitimlerin gerçekleştirilmesi ülkelerin teknolojik alt yapı ve yeterliliklerinin önemini tekrar hatırlatmıştır. Hem bu süreçte yapılan çalışmalar hem de bu sürecin PISA sınavlarına yansıması açısından araştırmalar yapılabilir.

\section{Kaynaklar}

Akbaba Altun, S. (2006). Complexity of Integrating Computer Technologies into Education in Turkey. Educational Technology \& Society, 9(1), 176-187. Erişim adresi: https://www.jstor.org/

Akıncı, A., Kurtoğlu, M. ve Seferoğlu, S. S. (2012). Bir teknoloji politikası olarak FATíH projesinin başarılı olması için yapılması gerekenler: Bir durum analizi çalışması. Akademik Bilişim Konferansında sunulan bildiri, Uşak Üniversitesi, UŞAK. Erişim adresi: https://ab.org.tr/ab12/bildiri/160.pdf 
Așkar, P. ve Olkun, S., (2005). PISA 2003 Sonuçları Açısından Okullarda Bilgi ve İletişim Teknolojileri Kullanımı. Eğitim Araştırmaları Dergisi, 19, 15-34. Erişim adresi: https://www.ebsco.com/

Aydın, A., Selvitopu, A. ve Kaya, M. (2018). Eğitime Yapılan Yatırımlar ve PISA 2015 Sonuçları Karşılaştırmalı Bir İnceleme. İlköğretim Online, 17(3), 1283-1301. Erişim adresi: https://www.ilkogretim-online.org/

Aydoğdu İskenderoğlu, T. ve Baki, A. (2011). İlköğretim 8. Sınıf Matematik Ders Kitabındaki Soruların PISA Matematik Yeterlik Düzeylerine Göre Sınıflandırılması. Eğitim ve Bilim, 36(161), 287-301. Erişim adresi: http://egitimvebilim.ted.org.tr/index.php/EB

Alessi, S. M. ve Shih, Y.F. (1989). The growth of computer-assisted instruction in Taiwan schools. Computers and Education, 13(4), 337-341. doi: 10.1016/03601315(89)90049-3

Bakioğlu, A. ve Baltacı, R. (2019). Çin'de Eğitim. Ankara: Nobel Akademi Yayıncılık.

Bayrakçı, M. (2005). Ders kitapları konusu ve ilköğretimde ücretsiz ders kitabı dağıtımı projesi. Milli Eğitim Dergisi, 165, 7-20. Erişim adresi: https://dhgm.meb.gov.tr/

Beijing Education Bureau. (2006). The 11th municipal plan of school education from 2006 to 2010. Erişim adresi: http://www.gov.cn/test/2006-02/07/content_180521.htm.

Beijing Education Bureau. (2015). Beijing initiated the project of enhancing K-12 inservice teachers' competency in infusing ICT into education. Erişim adresi: http://www.moe.edu.cn/publicfiles/business/htmlfiles/moe/s5147/201505/18773 4.html.

Bober, M. J. (2002). Technology integration: The difficulties inherent in measuring pedagogical change. TechTrends, 46(1), 21-23. Erişim adresi: https://www.springer.com/journal/11528

Bozkurt, B. Ü. (2014). PISA 2000'den PISA 2009'a Güney Kore'de okuma becerisinin gelişimi. Eğitim ve Bilim, 39(173), 140-154. Erişim adresi: http://213.14.10.181/index.php/EB/article/view/1949

Bowen, G. A. (2009). Document analysis as a qualitative research method. Qualitative Research Journal, 9(2), 27-40. doi:10.3316/QRJ0902027.

Çakır, R. ve Yıldırım, S. (2009). What Do Computer Teachers Think About the Factors Affecting Technology Integration in Schools? Elementary Education Online, 8(3), 952964. Erişim adresi: https://dergipark.org.tr/tr/pub/ilkonline

Çiftçi, S. ve Özok, H. İ. (2013). Türkiye'de ve Dünya'da seçmeli dersler: PISA ve TIMSS sınavlarının etkililiği. Tanhan, F., Aslan, C. ve Taşkın, N. (Ed.), Kesintili on iki yıllık zorunlu eğitim modelinde seçmeli dersler sempozyumu (s. 112-123) içinde. Van, Türkiye: Yüzüncü Yıl Üniversitesi. Erişim adresi: https://www.yyu.edu.tr/images/files/sempozyum.pdf\#page=122 
Çelen, F. K., Çelik, A. ve Seferoğlu, S. S. (2011). Türk eğitim sistemi ve PISA sonuçları. Akademik Bilişim Konferansında sunulan bildiri, İnönü University, Malatya. Erişim adresi: https://ab.org.tr/ab11/

Doğan, D., Çınar, M. ve Seferoğlu, S. S. (2016). “One Laptop per Child” projects and FATIH project: A comparative examination. SDU International Journal of Educational Studies, 3(1), 1-26. Erişim adresi: https://dergipark.org.tr/tr/pub/sduijes

Education Manpower Bureau (1998). Information Technology for Learning in a New Era: five-year strategy 1998/99 to 2002/03. Hong Kong: Education Manpower Bureau, Hong Kong SAR. Erişim adresi: https://www.info.gov.hk/archive/consult/1998/ited-e.pdf

Eryılmaz, S. ve Salman, Ş. (2014). Fatih projesi kapsamında yer alan öğretmen ve öğrencilerin projeden beklentileri ve bilişim teknolojileri kullanımına karşı algıları. Elektronik Mesleki Gelişim ve Araştırmalar Dergisi, 2(1), 46-63. Erişim adresi: https://dergipark.org.tr/tr/pub/yorumyonetim

Fiş Erümit, S., Gedik, N. ve Göktaş, Y. (2016). Türkiye'de Öğretim Teknolojilerinin Gelişimi:1984-2015 Dönemi. K. Çağıltay ve Y. Göktaş (Ed), Öğretim Teknolojilerinin Temelleri Teoriler, Araştırmalar, Eğilimler (s. 58-79) içinde. Ankara: Pegem Akademi.

Grzybowski, M. (2013). Educational technologies in South Korea. General and Professional Education, 2013(1), 3-9. Erişim adresi: http://genproedu.com/paper/2013-01/003-009.pdf

Gürcan, H. (2008). Bahçeşehir Fen ve Teknoloji Lisesi Öğrencilerinin BT Yeterliliklerinin Ölçülmesi Íçin Bir Model. (Yayınlanmamış yüksek lisans tezi). Bahçeşehir Üniversitesi, İstanbul.

Göktaş, Y., Yıldırım, Z. ve Yıldırım, S. (2008). The Keys for ICT Integration in K-12 Education: Teachers' Perceptions and Usage. H. U. Journal of Education, 34(1), $127-$ 139. Erişim adresi: http://www.efdergi.hacettepe.edu.tr/

Hsin, S.C. (1994). The Dynamism and Flexibility of Computer Technology Implementation in the Middle Schools in a Centralized Educational System. Paper presented at the Annual Meeting of the American Educational Research Association, New Orleans, LA. Erişim adresi: https://files.eric.ed.gov/fulltext/ED373776.pdf

Huang, R. H. (2009). What digital campus should focus on? Beijing Education, 8, 6-7.

Jang, S. (2014). Study on service models of digital textbooks in cloud computing environment for SMART education. International Journal of u-and e-Service, Science and Technology, 7(1), 73-82. Erişim adresi: http://sersc.org/journals/index.php/ijunesst

Kanemune, S., Shirai, S. ve Tani, S. (2017). Informatics and programming education at primary and secondary schools in Japan. Olympiads in Informatics, 11(2017), 143150. Erişim adresi: https://ioinformatics.org/page/ioi-journal/1 
Keser, H. (2011). Türkiye'de Bilgisayar Eğitiminde İlk Adim: Orta Öğretimde Bilgisayar Eğitimi İhtisas Komisyonu Raporu. Eğitim Teknolojisi Kuram ve Uygulama, 1(2), 8394. Erişim adresi: https://dergipark.org.tr/tr/pub/etku

Kılıçaslan, H. ve Yavuz, H. (2019). PISA Sonuçları ile Türkiye'de Eğitim Harcamaları İlişkisi. Bilgi Sosyal Bilimler Dergisi, 21(2), 296-319. Erişim adresi: https://dergipark.org.tr/tr/pub/bilgisosyal

Kim, T., Cho, J. Y. ve Lee, B. G. (2012). Evolution to smart learning in public education: a case study of Korean public education. T. Ley ve diğerleri (Ed), Proceedings of IFIP International Federation for Information Processing (s. 170-178) içinde. Berlin, Heidelberg: Springer.

Koh, T. S. ve Lee, S. C. (2008). Digital Skills and Education: Singapore's ICT Masterplanning for the School Sector. In S. K. Lee, C. B. Goh, B. Fredriksen, \& J. P. Tan (Eds.), Toward a better future: Education and training for economic development in Singapore since 1965 (pp. 167-190). Washington, DC: The World Bank.

Kong, S. C., Chan, T.-W., Huang, R. ve Cheah, H. M. (2014). A review of e-Learning policy in school education in Singapore, Hong Kong, Taiwan, and Beijing: Implications to future policy planning. Journal of Computers in Education, 1(2), 187-212. Erişim adresi: h https://www.springer.com/journal/40692

Kong, S. C., Looi, C. K., Chan, T. W. ve Huang, R. (2017). Teacher development in Singapore, Hong Kong, Taiwan, and Beijing for e-Learning in school education. Journal of Computers in Education, 4(1), 5-25. doi: 10.1007/s40692-016-0062-5

Küpçüoğlu, E. (2008). Bilişim teknolojilerinin temelleri: eğitimin ortaöğretimde interaktif yöntemlerle verilmesi. (Yayınlanmamış doktora tezi). Bahçeşehir Üniversitesi, İstanbul.

Lim, C. ve Kye, B. (2019). Classroom Revolution through SMART Education in the Republic of Korea. Paris United Nations Educational, Scientific and Cultural Organization. Erişim adresi: https://unesdoc.unesco.org/ark:/48223/pf0000366729

Luke, A., Freebody, P., Lau, S. ve Gopinathan, S. (2005). Towards research-based innovation and reform: Singapore schooling in transition. Asia Pacific Journal of Education, 25(1), 5-28. doi: 10.1080/02188790500032467

Mau, S. (1988). The research and diffusion of computer-assisted instruction. Bulletin of the National Institute of Educational Materials, 14, 277-286. Erişim adresi: https://nie.edu.sg/about-us/publication/

Milli Eğitim Bakanlığı (2005). 2006 Malî Yılı Bütçesine İlişsin Rapor. Ankara: Devlet Kitapları Müdürlüğü Basımevi.

Milli Eğitim Bakanlığı (2011). PISA TÜRKIYYE, Yenilik ve Eğitim Teknolojileri Genel Müdürlügü. $\quad$ Erişim adresi: http://pisa.meb.gov.tr/wpcontent/uploads/2013/07/PISA-kitab\%C4\%B1.pdf 
Milli Eğitim Bakanlığı (2012). FATïH, Eğitimde Geleceğe Açılan Kapı. Erişim adresi: http://fatihprojesi.meb.gov.tr/

Milli Eğitim Bakanlığı (2020a). FATï Projesi. Erişim adresi: http://fatihprojesi.meb.gov.tr/

Milli Eğitim Bakanlığı (2020b.) Türkiye, Koronavirüs Salgınında Ulusal Çapta Uzaktan Eğitim Veren 2 Ülkeden Biri. Erişim adresi: http://www.meb.gov.tr/turkiyekoronavirus-salgininda-ulusal-capta-uzaktan-egitim-veren-2-ulkedenbiri/haber/20618/tr

Ministry of Education, Republic of China-Taiwan (1996). Ministry of Education Republic of China (Taiwan). Educational technology in Taiwan: Current and future, Ministry of Education in Taiwan, Taipei.

Ministry of Education, Republic of China-Taiwan (1998). Ministry of Education Republic of China (Taiwan). Educational technology curriculums, Ministry of Education in Taiwan, Taipei.

Naito, S. ve Hausman, B. (2005). Information and communications technology in Japan. A general overview of the current Japanese initiatives and trends in the area of ICT. Erişim adresi: http://www.vinnova.se/upload/EPiStorePDF/vr-05-04.pdf

Organisation for Economic Co-operation and Development (2009). PISA 2009 assessment framework, Retrieved December 12, 2019, from http://www.oecd.org/dataoecd/11/40/44455820.pdf.

Organisation for Economic Co-operation and Development (2012a). PISA 2012 Results in Focus What 15-year-olds know and what they can do with what they know. Retrieved May 7, 2020 from https://www.oecd.org/pisa/keyfindings/pisa-2012-resultsoverview.pdf

Organisation for Economic Co-operation and Development (2012b). Lessons from PISA for Japan, Strong Performers and Successful Reformers in Education, OECD Publishing. Erişim adresi: http://dx.doi.org/10.1787/9789264118539-en

Organisation for Economic Co-operation and Development (2018). Education at a Glance 2018: OECD Indicators, Paris: OECD Publishing. Erişim adresi: https://doi.org/10.1787/eag-2018-en.

Özdemir, S. (2010). To Err is Human, but to Persist İs Diabolical: Loss of Organizational Memory and E-Learning Projects. Computers \& Education, 55(1), 101-108. Erişim adresi: https://www.journals.elsevier.com/computers-and-education

Özekicioğlu, H. ve Kılıç, C. (2017). Küresel ekonomi çağında Çin ve Hindistan. Íktisat politikası araştırmaları dergisi, 4(2), 19-34. Erişim adresi: https://dergipark.org.tr/en/download/article-file/330038

Özkan, M., Özkan, Y. Ö. ve Güvendir, M. A. (2019). Türkiye ve Singapur Okullarının Öğretmenlerin Mesleki Gelişimleri ve Öğrenimi Aksatan Öğretmen Davranışları 
Açısından İncelenmesi. Eğitim ve Bilim, 44(198). Erişim adresi: http://egitimvebilim.ted.org.tr/index.php/EB

Prais, S.J. (2004). Cautions on OECD’s Recent Educational Survey (PISA): Rejoinder to OECD's Response. Oxford Review of Education, 30(4), 569-573. doi: 10.1080/0305498042000303017

Skryabin, M., Zhang, J., Liu, L. ve Zhang, D. (2015). How the ICT development level and usage influence student achievement in reading, mathematics, and science? Computers \& Education, 85, 49-58. doi: 10.1016/j.compedu.2015.02.004

Singapore Educational Technology Division (2008). 3rd Masterplan for ICT in education. Erişim adresi: http://ictconnection.moe.edu.sg/cos/o.x?c=/ictconnection/pagetree\&func=view\&rid $=665$.

Singapore Educational Technology Division (2016). 4th Masterplan for ICT in education. Erişim adresi: https://ictconnection.moe.edu.sg/Masterplan-4/vision-and-goals

Starateji ve Bütçe Başkanlığı (2019). Yedinici Beş Yıllık Kalkınma Planı (1996-2000). Erişim adresi: https://www.sbb.gov.tr/wp-content/uploads/2018/11/YedinciBe\%C5\%9F-Y\%C4\%B1ll\%C4\%B1k-Kalk\%C4\%B1nma-Plan\%C4\%B1-19962000\%E2\%80\%8B.pdf

Şendurur, P. ve Arslan, S. (2017). Eğitimde teknoloji entegrasyonunu etkileyen faktörlerdeki değişim. Mehmet Akif Ersoy Üniversitesi Eğitim Fakültesi Dergisi, 43, 2550.

Tanrısevdi, F. ve Kıral, B. (2018). Çin ve Türk Eğitim Sisteminin Karşılaştırılması. Çağdaş Yönetim Bilimleri Dergisi, 5(3), 223-240. Erişim adresi: https://dergipark.org.tr/tr/pub/cybd

Tayvan (15 Ocak, 2021). Vikipedi. Erişim adresi: https://tr.wikipedia.org/wiki/Tayvan

Topu, F. B. (2010). Bilişim teknolojileri öğretmenlerinin okullarındaki rolleri, beklentiler ve karşılaşılan problemler: Erzurum ili örneği. (Yayınlanmamış yüksek lisans tezi). Atatürk Universitesi, Erzurum.

Tygret, J.A. (2017). The influence of student teachers on student achievement: A case study of teacher perspectives. Teaching and Teacher Education: An International Journal of Research and Studies, 66(1), 117-126. doi: 10.1016/j.tate.2017.04.005

Usa, C. H. T. ve Twu, H. L. (2002). Educational technology in Taiwan. Educational Media International, 39(2), 153-164. doi: 10.1080/09523980210153444

UNESCO (2008). Strategy framework for promoting ICT literacy in the Asia-Pacific region, UNESCO Bangkok

Communication and Information Unit. Erişim adresi: https://unesdoc.unesco.org/ark:/48223/pf0000162157_eng 
Usluel, Y., Kuskaya-Mumcu, F. ve Demiraslan, Y. (2007). ICT in teaching-learning process: Teachers' views on the integration of ICT and on the perceived obstacles to this integration. Hacettepe University Journal of Education, 32, 164-179. Erişim adresi: http://www.efdergi.hacettepe.edu.tr/

Uşun, S. (2004). Undergraduate Students Attitudes on the Use of Computers in Education. Turkish Online Journal of Educational Technology-TOJET, 3(2), 62-70. Erişim adresi: http://www.tojet.net/

Wong, E. M. ve Li, S. C. (2006). Is ICT a lever for educational change? A study of the impact of ICT implementation on teaching and learning in Hong Kong. Informatics in Education, 5(2), 317-329. Erişim adresi: https://infedu.vu.lt/journal/INFEDU

Wu, D. (2014). An introduction to ICT in education in China. R. Huang ve diğerleri. (Ed), ICT in Education in Global Context (s. 65-84) içinde. Berlin, Heidelberg: Springer.

Vallance, M. (2008). Beyond policy: Strategic actions to support ICT integration in Japanese schools. Australasian Journal of Educational Technology, 24(3). doi: 10.14742/ajet.1209

Vogt, F. ve Rogalla, M. (2009). Developing adaptive teaching competency through coaching. Teaching and Teacher Education, 25(8), 1051-1060. doi: 10.1016/j.tate.2009.04.002

Yardımcıoğlu, F. ve T. Gürdal (2012). Türkiye'de Eğitimin Niteliğinin OECD ve AB Ülkeleri İle Karşılaştırmalı Bir Analizi. Finans Politik ve Ekonomik Yorumlar, 49(570), 35-50. Erişim adresi: http://www.ekonomikyorumlar.com.tr/

Yıldırım, A. ve Şimşek, H. (2008). Sosyal Bilimlerde Nitel Araştırma Yöntemleri (6. Baskı). Ankara: Seçkin Yayıncılık.

Yıldız, T. (2008). Öğretmenler İçin İnteraktif Test Geliştirme Platformu. (Yayınlanmamış yüksek lisans tezi). Bahçeşehir Üniversitesi, İstanbul.

Yiğit, A. M. (2013). Teachers' attitudes towards the "dyned" in primary education in Turkey. Journal of Educational \& Instructional Studies in the World, 3(3), 56-65. Erişim adresi: http://wjeis.org

Yurttaş Kumlu, G. D. (2018). Türkiye'de PISA uygulamasına katılan öğrencilerin bilgi ve iletişim teknolojilerine erişimlerinin PISA sonuçlarını yordama düzeyleri. (Yayınlanmamış yüksek lisans tezi). Hacettepe Üniversitesi, Ankara.

Zhu, Z., Gu, X, Collis, B. ve Moonen, J. (2011). Use of ICT in Chinese schools: Striving for educational quality and equality. Educational Technology, 51(3), 32-37. Erişim adresi: https://www.jstor.org/ 
$\mathrm{Bu}$ çalışma için etik kurul izni 27.11.2020 tarih ve 81614018-000-E.533 sayılı Trabzon Üniversitesi Rektörlüğü Etik Kurulu'ndan alınmıştır.

\begin{tabular}{|l|}
\hline Araştırmacıların Makaleye Katkı Oranı Beyanı: \\
1. yazar katkı oranı: $\% 50$ \\
2. yazar katkı oranı: \%50 \\
\hline Çıkar Çatışması Beyanı: \\
Yok. \\
\hline Finansal Destek veya Teşekkür Beyanı \\
Bu çalıșma için herhangi bir kurumdan finansal destek alınmamıștır. \\
\hline
\end{tabular}


